Research paper

\title{
Response of marine palynomorphs to Neogene climate cooling in the Iceland Sea (ODP Hole 907A)
}

\author{
M. Schreck*, M. Meheust, R. Stein, J. Matthiessen \\ Alfred Wegener Institute for Polar and Marine Research, Am Alten Hafen 26, 27568 Bremerhaven, Germany
}

\section{A R T I C L E I N F O}

\section{Article history:}

Received 23 May 2012

Received in revised form 20 February 2013

Accepted 13 March 2013

\section{Keywords:}

Iceland Sea

Neogene

dinoflagellate cysts

acritarchs

alkenone

paleoenvironment

\begin{abstract}
A B S T R A C T
The present study on ODP Leg 151 Hole 907A combines a detailed analysis of marine palynomorphs (dinoflagellate cysts, prasinophytes, and acritarchs) and a low-resolution alkenone-based sea-surface temperature (SST) record for the interval between 14.5 and $2.5 \mathrm{Ma}$, and allows to investigate the relationship between palynomorph assemblages and the paleoenvironmental evolution of the Iceland Sea.

A high marine productivity is indicated in the Middle Miocene, and palynomorphs and SSTs both mirror the subsequent long-term Neogene climate deterioration. The diverse Middle Miocene palynomorph assemblages clearly diminish towards the impoverished assemblages of the Late Pliocene; parallel with a somewhat gradual decrease of SSTs being as high as $20{ }^{\circ} \mathrm{C}$ at $\sim 13.5 \mathrm{Ma}$ to around $8{ }^{\circ} \mathrm{C}$ at $\sim 3 \mathrm{Ma}$.

Superimposed, palynomorph assemblages not only reflect Middle to Late Miocene climate variability partly coinciding with the short-lived global Miocene isotope events (Mi-events), but also the initiation of a proto-thermohaline circulation across the Middle Miocene Climate Transition, which led to increased meridionality in the Nordic Seas. Last occurrences of species cluster during three events in the Late Miocene to Early Pliocene and are ascribed to the progressive strengthening and freshening of the proto-East Greenland Current towards modern conditions. A significant high latitude cooling between 6.5 and 6 Ma is depicted by the supraregional "Decahedrella event" coeval with lowest Miocene productivity and a SST decline.

In the Early Pliocene, a transient warming is accompanied by surface water stratification and increased productivity that likely reflects a high latitude response to the global biogenic bloom. The succeeding crash in palynomorph accumulation, and a subsequent interval virtually barren of marine palynomorphs may be attributed to enhanced bottom water oxygenation and substantial sea ice cover, and indicates that conditions seriously affecting marine productivity in the Iceland Sea were already established well before the marked expansion of the Greenland Ice Sheet at 3.3 Ma.
\end{abstract}

(C) 2013 Elsevier B.V. All rights reserved.

\section{Introduction}

The Neogene is a crucial epoch for the evolution of Earth's climate as it went through the fundamental transition from a relatively warm Early Miocene to the colder conditions at the end of the Pliocene (Zachos et al., 2008). After the Miocene Climate Optimum (MCO, 17-15 Ma), when Earth experienced warmest temperatures since the Middle Eocene (Zachos et al., 2008), global surface and deep ocean temperatures cooled significantly (Wright et al., 1992; Billups and Schrag, 2002; Shevenell et al., 2004; Kuhnert et al., 2009) across the Middle Miocene Climate Transition (MMCT, 14.2-13.7 Ma), and the East Antarctic Ice Sheet experienced major expansion (e.g. Flower and Kennett, 1994; John et al., 2011; Paschier et al., 2011). This transition marked the onset of progressive long-term cooling both on land (Pound et al., 2012) and in sea (Zachos et al., 2008) that ultimately

\footnotetext{
* Corresponding author at: Korea Polar Research Institute, Get-Pearl-Tower, 12 Gaetbeol-ro, Incheon, Korea. Tel.: +82 322606008.

E-mail address: Michael.Schreck@kopri.re.kr (M. Schreck).
}

pushed the climate system into the bipolar glaciated mode of today. Superimposed, distinct short-term climate variability has been observed in marine records (Miller et al., 1991; Turco et al., 2001; Andersson and Jansen, 2003; Westerhold et al., 2005; John et al., 2011) and partly attributed to ice sheet growth on Antarctica and/or bottom-water cooling (Mi events sensu Miller et al., 1991). In this context, however, the high northern latitude oceans are of eminent relevance to decipher causes and consequences of the Neogene climate variability (e.g. Thiede et al., 1998) since they influence global climate through feedback mechanisms related to the formation of perennial/ seasonal sea ice cover (Miller et al., 2010; Serreze and Barry, 2011), and production of northern-sourced deep-water (Flower and Kennett, 1994; Rahmstorf, 2006).

The timing of the onset of glaciations in the Northern Hemisphere is still debated but ice-rafted debris (IRD) has been recorded as early as the Middle Eocene in the Arctic Ocean (Stickley et al., 2009) and the Greenland Sea (Eldrett et al., 2007; Tripati et al., 2008). Although it has been speculated that a Neogene Greenland Ice Sheet has existed since at least $18 \mathrm{Ma}$ (Thiede et al., 2011), published records suggest that 
small scale glaciations large enough to reach sea-level might have occurred on Greenland not before the early to middle Late Miocene (Schaeffer and Spiegler, 1986; Wolf and Thiede, 1991; Fronval and Jansen, 1996; Wolf-Welling et al., 1996; Helland and Holmes, 1997; Winkler et al., 2002). In contrast, ice sheets probably developed in the northern Barents Sea and on Scandinavia already in the Middle Miocene (Fronval and Jansen, 1996; Knies and Gaina, 2008).

The formation of glacial ice on the circum-Arctic continents might have been linked to the fundamental reorganization of the circulation in the Nordic Seas. The opening of Fram Strait and the subsidence of the Greenland-Scotland Ridge (GSR) have led to an enhanced exchange of water masses between the Arctic Ocean and the North Atlantic via the Nordic Seas (Bohrmann et al., 1990; Wright and Miller, 1996; Poore et al., 2006; Jakobsson et al., 2007; Knies and Gaina, 2008). Jakobsson et al. (2007) assumed that Fram Strait reached sufficient width (40-50 km; present-day width $400 \mathrm{~km}$ ) to efficiently ventilate the Arctic Ocean at $\sim 17.5 \mathrm{Ma}$, and began to open at greater depth by $\sim 14 \mathrm{Ma}$, which is supported by benthic foraminiferal evidence from the Lomonosov Ridge and Fram Strait (Kaminski et al., 2006; Kaminski, 2007). Simultaneously, a prominent shift from biosiliceous to calcareous-rich sediments in the Norwegian Sea (Bohrmann et al., 1990; Cortese et al., 2004) was likely coupled to the subsidence of the Greenland-Scotland Ridge, which consequently modulated exchange of North Atlantic and Arctic water masses. Reduced fluxes in Northern Component Water (NCW) have been correlated with uplifts of the GSR and vice versa (Wright and Miller, 1996; Poore et al., 2006; Abelson et al., 2008), and Bohrmann et al. (1990) related periodic changes in biogenic carbonate and opal accumulation in the Norwegian Sea to variable exchange of surface waters between the Nordic Seas and the North Atlantic. The initiation of a proto-East Greenland Current (EGC) may have coincided with the establishment of a modern-like ice drift pattern through Fram Strait at around $14 \mathrm{Ma}$ (Knies and Gaina, 2008), but Wei (1998) suggest an onset around 12 Ma based on calcareous nannofossils from the Irminger Basin. An even younger onset at around $10.5 \mathrm{Ma}$ is proposed by Wolf-Welling et al. (1996) based on changes in bulk accumulation rates in the Fram Strait. The modern EGC was probably first established during the intensification of Northern Hemisphere glaciations with the thermal isolation of Greenland due to the final closure of the Isthmus of Panama and the opening of Bering Strait at the Pliocene-Quaternary transition (Sarnthein et al., 2009).

However, to date, most information is derived from a few Neogene sections located along the path of the inflowing North Atlantic waters in the Norwegian Sea (Fig. 1) while the Neogene paleoceanography of the Greenland and Iceland seas is almost unknown due to the discontinuous occurrence of calcareous microfossils in these sediments (e.g. Fronval and Jansen, 1996). Here we present a comparatively high-resolution record of organic-walled microfossils (e.g. dinoflagellate cysts $=$ dinocysts, prasinophytes, acritarchs) from the almost continuous middle Miocene to upper Pliocene sequence of ODP Hole 907A in the Iceland Sea, an area close to the growing Greenland and Iceland ice sheets, which experienced the effects of sea ice cover, migrating wind fronts and ocean currents. The pristine paleomagnetic record of Hole 907A provides the unique opportunity for detailed investigations on the response of palynomorph assemblages to the MMCT and subsequent long-term cooling, and thus to derive complementary information on the Neogene of the Nordic Seas cold-water domain. Palynomorphbased interpretations have been supplemented with a low-resolution alkenone SST record that provides new constraints on the thermal evolution of the Iceland Sea.

\section{Material and methods}

ODP Hole $907 \mathrm{~A}$ is located on the eastern Iceland Plateau $\left(69^{\circ} 14.989^{\prime}\right.$ N, 12 $41.894^{\prime}$ W; 2035.7 m water depth; Fig. 1), and was drilled in an undisturbed hemipelagic sequence that mainly consists of unlithified silty clays and clayey silts (Shipboard Scientific Party, 1995). Based on the revised magnetostratigraphy (Channell et al., 1999), which has been adjusted to the latest astronomically-tuned Neogene timescale (ATNTS) 2004 (Lourens et al., 2005), a total of 120 samples spanning the early Middle Miocene to Pliocene (Samples $23 \mathrm{H}-\mathrm{CC}, 10-12 \mathrm{~cm}$ to $6 \mathrm{H}-3,82-84 \mathrm{~cm}$ ), has been selected at $\sim 100 \mathrm{kyr}$ resolution. The stratigraphic occurrence of a selected number of dinocyst and acritarch species is discussed by Schreck et al. (2012).

\subsection{Palynological methods}

Subsamples $\left(\sim 15 \mathrm{~cm}^{3}\right)$ were processed using standard palynological techniques (e.g. Wood et al., 1996), including acid treatment ( $\mathrm{HCl}$ [10\%], HF [38-40\%]), but without oxidation or alkali treatments. 2 Lycopodium clavatum tablets (Batch no. $124961, \mathrm{X}=12,542, \mathrm{~s}= \pm 416$ per tablet) were added to each sample during the $\mathrm{HCl}$ treatment to calculate palynomorph concentrations (Stockmarr, 1977). The residue was sieved over a $6 \mu \mathrm{m}$ polyester mesh to ensure that small palynomorphs

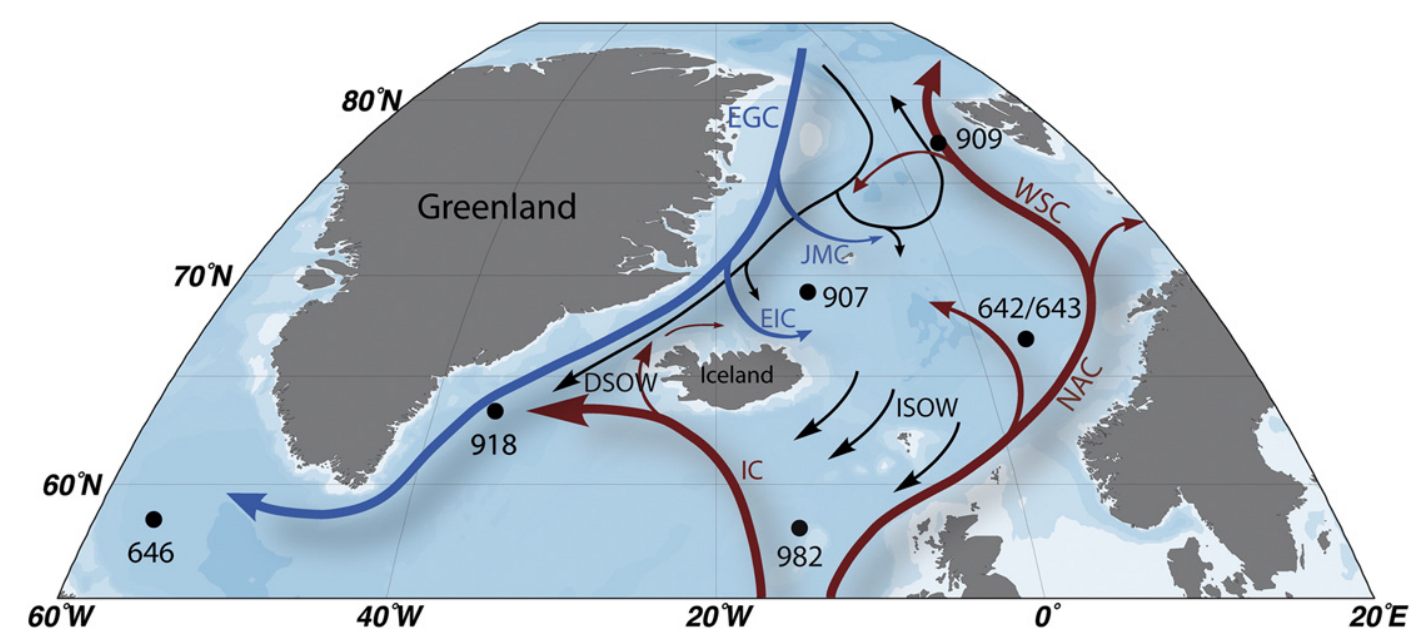

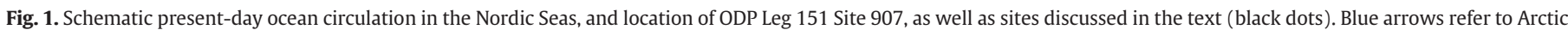

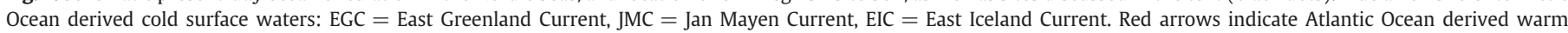

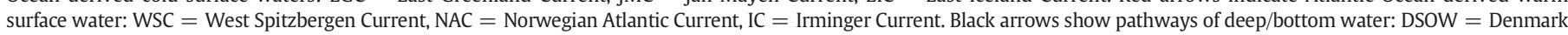
Strait Overflow Water; ISOW = Iceland Scotland Overflow Water (modified from Blindheim and Østerhus, 2005). 
$(<15 \mu \mathrm{m})$ would be retained, and mounted with glycerine jelly on microscope slides.

Generally, marine palynomorphs have been counted until a minimum of $350(\varnothing=272)$ dinocysts had been enumerated. At least one slide was completely scanned for rare taxa not encountered during regular counts. All counts and scans were conducted on a Zeiss Axioplan 2 microscope at $63 \times$ and $20 \times$ magnification, respectively. Transmitted light photomicrographs (Plates I-III) have been taken with a JenaOptik ProgRes C5 digital camera. Autofluorescence has been determined by epifluorescence microscopy using a Zeiss Axiophot microscope equipped with the Zeiss filter set 9 (BP 450-490, FT 510; LP 515).

The dinocyst nomenclature follows Fensome and Williams (2004 and references therein), Schreck et al. (2012), and Schreck and Matthiessen (in press), and acritarch and prasinophyte nomenclature follows Head et al. (1989a), Manum (1997), Head (2003), and De Schepper and Head (2008).

The Shannon-Wiener index was calculated for the dinocyst assemblage as a statistical measure of diversity as

$H^{\prime}=\sum_{i=1}^{s}\left(p_{i}\right)\left(\log _{2} p_{i}^{2}\right)$

with $s=$ number of species, and $p_{i}=$ proportion of total sample belonging to $i$ th species. As a more simple measure for diversity, we present species richness, which equals the number of dinocyst taxa recorded in a sample. The Shannon-Wiener Index is based on information theory and independent of sample size, and tries to measure the amount of order (or disorder) contained in a system (Krebs, 1998). Therefore, this index also provides information on the heterogeneity of an assemblage. As the total number of species is known by species richness, the differences between both diversity measures are partly on account of relative shifts within the dinocyst assemblage.

\subsection{Organic geochemical methods}

Sedimentary total organic carbon (TOC) contents were determined for all 120 samples by means of a carbon-sulfur determinator (CS-125, Leco) after the removal of carbonates by adding hydrochloric acid. Total carbon and nitrogen contents were measured by a CNS analyzer (Elementar III, Vario) and used to calculate $\mathrm{C} / \mathrm{N}$ ratios.

For an initial study on alkenones, a subset of 10 samples has been selected (Table 1). The freeze-dried and homogenized sediments (2 to $4 \mathrm{~g}$ ) were extracted with an Accelerated Solvent Extractor (DIONEX, ASE 200; $100{ }^{\circ} \mathrm{C}, 1600 \mathrm{psi}, 15 \mathrm{~min}$ ) using dichloromethane and methanol $(99: 1, v / v)$ as solvent. The neutral fraction was dissolved in hexane. The separation of compounds was carried out by open column chromatography $\left(\mathrm{SiO}_{2}\right)$ using $n$-hexane and dichloromethane $(1: 1, \mathrm{v} / \mathrm{v})$, and dichloromethane. The composition of alkenones was analyzed with a Hewlett Packard gas chromatograph (HP 6890, column $60 \mathrm{~m} \times$ $0.32 \mathrm{~mm}$; film thickness $0.25 \mu \mathrm{m}$; liquid phase: DB1-MS) using a temperature program as follows: $60{ }^{\circ} \mathrm{C}$ ( $3 \mathrm{~min}$.), $150{ }^{\circ} \mathrm{C}$ (rate: $20{ }^{\circ} \mathrm{C} / \mathrm{min}$.), $320{ }^{\circ} \mathrm{C}$ (rate: $6{ }^{\circ} \mathrm{C} / \mathrm{min}$.), and $320{ }^{\circ} \mathrm{C}$ (40 min. isothermal). For splitless injection, a cold injection system (CIS) was used $\left(60{ }^{\circ} \mathrm{C}\right.$ [6 s], $340{ }^{\circ} \mathrm{C}$ [rate: $12{ }^{\circ} \mathrm{C} / \mathrm{s}$ ], $340{ }^{\circ} \mathrm{C}$ [ $1 \mathrm{~min}$. isothermal]). Helium was used as carrier gas $\left(1.2 \mathrm{ml} / \mathrm{min}\right.$.). Individual alkenone $\left(\mathrm{C}_{37: 3}, \mathrm{C}_{37: 2}\right)$ identification is based on retention time and the comparison with an external standard, which was also used for controlling the instrument stability. The alkenone unsaturation index $U^{K^{\prime}}{ }_{37}$ and hence the mean annual sea-surface temperature (SST in ${ }^{\circ} \mathrm{C}$ ) was calculated as $U^{K^{\prime}}{ }_{37}=$ $0.033 \mathrm{~T}+0.044$ according to Müller et al. (1998). The error of the calibration equation is $\pm 1{ }^{\circ} \mathrm{C}$ (Müller et al., 1998). The $U^{K}{ }_{37}$ index may be more appropriate in the present-day Nordic Seas (Bendle and
Rosell-Melé, 2004) but could not be calculated due to low abundance of tetra-unsaturated alkenones.

\subsection{Reliability of the $U^{K^{\prime}}{ }_{37}$ index in the Neogene}

In recent sediments alkenones are mainly produced by the ubiquitous coccolithophorid Emiliania huxleyi (e.g. Volkman et al., 1995), a haptophyte that first appeared in the late Quaternary about $268 \mathrm{kyr}$ ago (Thierstein et al., 1977). In pre-Quaternary sediments, long-chain alkenones are attributed to the morphologically related genera of the family Gephyrocapsaceae (Marlowe et al., 1990). Previous studies have shown that these species can be used for $U^{K^{\prime}}{ }_{37}$ and global core-top calibration without significant differences in SST dependence compared to E. huxleyi (e.g. Villanueva et al., 2002; McClymont et al., 2005). SST records for the Pliocene (Dekens et al., 2007; Lawrence et al., 2009, 2010; Naafs et al., 2010; Seki et al., 2012), Miocene (Herbert and Schuffert, 1998; Mercer and Zhao, 2004; Huang et al., 2007; Rommerskirchen et al., 2011; LaRiviere et al., 2012; Rousselle et al., 2013), and lowermost Miocene and Eocene (Weller and Stein, 2008) demonstrate the capability to obtain reliable temperature estimates on pre-Quaternary time scales.

The input of allochthonous alkenones seems to be of some importance in the modern Nordic Seas (Bendle et al., 2005). However, coccolithophorids, dinoflagellates and prasinophytes are flagellates sharing the same habitat and thus biotic and abiotic processes should affect the communities in the same way. As reworking of dinocysts is very low $(<1 \%)$ the input of allochthonous alkenones should be restricted and likely not significantly affect our SST estimates. Furthermore, post-depositional processes may affect the preservation of organic matter and alkenones (e.g. Rommerskirchen et al., 2011), with oxygen as one of the most destructive agents (Zonneveld et al., 2010). As dinocysts, which are sensitive to oxygenic degradation (Zonneveld et al., 2008), exhibit high concentration throughout most of the sequence, this effect is assumed to have only a minor influence on the record.

On global scale, $U^{K^{\prime}}{ }_{37}$ shows the best statistical relationship to mean annual SST, as the production of alkenones is not limited to summer in most regions (Müller et al., 1998). In the Nordic Seas, however, coccolithophorid production today is considerably higher during summer than in the "non-production" period from autumn to early summer (e.g. Andruleit, 1997; Schröder-Ritzrau et al., 2001). These seasonal fluctuations in alkenone production may cause a shift towards a summer bias in temperature (Conte et al., 2006). We also acknowledge that alkenone production may have shifted during the time span of our study and might have been less seasonal in the warm Miocene.

\section{Results}

\subsection{Palynomorph assemblages}

Hole 907A yielded a diverse and moderate to well preserved palynomorph assemblage, where 84 samples contained enough material to enumerate a statistically relevant quantity of 350 dinocysts. Counts in 36 samples ranged between 0 and 196 dinocysts of which 21 samples are virtually barren ( $<10$ cysts/slide). The majority of these samples cluster in two distinctive intervals between c. 8.1-7.4 Ma (Late Miocene, 100-103 mbsf) and c. 4.1-2.6 Ma (Middle to Late Pliocene, 49-62 mbsf; Fig. 2). Both intervals are also barren of acritarchs and prasinophytes. The relative abundance and concentration of the palynomorph groups and the distribution of the dinocyst taxa used for paleoenvironmental interpretation in Hole 907A are shown in Fig. 2 and Fig. 3. Raw counts and stratigraphic ranges of all taxa encountered are provided in Appendix A. To avoid spurious abundance peaks all samples with less than 50 dinocysts counted have been omitted from all figures. 


\subsection{In-situ dinocysts}

Dinocysts are the most abundant and diverse palynomorph group (Fig. 2), comprising at least 151 species belonging to at least 43 genera. A large number of these species are apparently not formally described, and only 23 are extant (Appendix A).

The Batiacasphaera micropapillata complex and Nematosphaeropsis labyrinthus represent more than $50 \%$ of the assemblages in most samples, and are usually inversely correlated (Fig. 3). Accompanying taxa regularly recorded are shown in Fig. 3, but only Batiacasphaera sphaerica, Habibacysta tectata, Labyrinthodinium truncatum, Spiniferites spp. and Protoperidinium spp. continuously contribute more than 10\% to the assemblage in some intervals. Moreover, 97 species occur in five or less samples and 31 of these are recovered in one sample only. Seventy-nine of these 97 species are rare $(<2 \%)$ whereas seven of these are abundant $(>15 \%)$ in one sample but are rarely recorded in adjacent samples, which seriously restrict the utility of most species for interpretation. Another 14 species are recorded only outside the regular counts (Appendix A).

The Middle to middle Late Miocene assemblages are characterized by a high species richness with more than 30 taxa recovered routinely, accompanied by concentrations ranging from 10,000 to 40,000 cysts/g sediment, being exceptionally even higher (Fig. 2). The highest concentrations are attributed to low counts of Lycopodium spores. Thus, absolute values are subject to statistical uncertainty but trends are reliable. After maximum values in the Langhian, concentration decreases in the Serravallian to a minimum around 5000 cysts/g sediment, but reaches average values higher than 20,000 cysts/g sediment again in the lower to mid-Tortonian before it declines to an average of 15,000 cysts/g sediment during the mid-Tortonian to mid-Messinian. Latest Miocene and Pliocene cyst concentration is comparatively low (ø 1340 cysts/g sediment), and the number of encountered taxa rarely exceeds 20 per sample, with the majority varying around 10 species. Late Pliocene assemblages usually contain less than 10 species (Fig. 2).

Although dinocyst diversity is comparatively high throughout Middle to Late Miocene times, three distinctive events are highlighted by the Shannon-Wiener index: 1) a significant decrease between 14.5 and 13.7 Ma, followed by 2) an increase to maximum values at $\sim 10.7 \mathrm{Ma}$, and 3) a subsequent long-term decline until a significant drop at $\sim 7.0 \mathrm{Ma}$, which is interrupted by a prominent barren interval between 8.1 and $7.4 \mathrm{Ma}$ (Fig. 2). The species richness generally displays the same trend. The crucial difference, however, is a distinct short-term decline between 12.3 and $11.7 \mathrm{Ma}$, which is not clearly reflected in the Shannon-Wiener index.

The lowermost part of the hole is characterized by abundant to dominant B. sphaerica and L. truncatum, and common Palaeocystodinium spp., which all decrease until $\sim 14.0$ Ma when the B. micropapillata complex increases significantly. This complex exhibits cyclic variations with temporarily reduced abundances but is characterized by a general decrease towards the middle Late Miocene (Fig. 3). A distinct shift is marked by a minimum of the B. micropapillata complex at $\sim 13$ Ma associated with a minimum of $B$. sphaerica, and $N$. labyrinthus, $H$. tectata, Impagidinium pallidum, Impagidinium cf. pacificum, and Cerebrocysta irregulare were abundant for the first time.
The gradual Late Miocene decline in diversity is punctuated by major transitions in assemblage composition at $\sim 10.6-10.2 \mathrm{Ma}$ and 9-8.3 Ma, when several species disappeared (Table 2, Fig. 3). Batiacasphaera sphaerica and Reticulatosphaera actinocoronata have their highest common occurrence (HCO) at 10 Ma while Spiniferites spp. and $H$. tectata decrease during this interval, the latter significantly after a remarkable acme at $\sim 10 \mathrm{Ma}$ (Fig. 3).

After the barren interval between 8.1 and 7.4 Ma, the B. micropapillata complex is still present but in considerably lower numbers, and $N$. labyrinthus is predominant in most of the samples. Another major turnover at $\sim 4.5$ to $4.3 \mathrm{Ma}$ is marked by a cluster of last occurrences (Table 2, Fig. 3), and the HCO of the B. micropapillata complex. At $\sim 4.2 \mathrm{Ma}, N$. labyrinthus disappeared abruptly and succeeding samples are virtually barren, interrupted by almost mono-specific Spiniferites spp. assemblages at 3.6 Ma, 3.4 Ma and 3.3 Ma only.

\subsubsection{Ecology}

For the interpretation of ecological affinities of extant species a vast data set has been compiled in the past decade (e.g. Rochon et al., 1999; Marret and Zonneveld, 2003; Bonnet et al., 2012; Zonneveld et al., in press). Since most species recorded in this study are extinct, however, it has been attempted to derive their ecological preferences based on paleobiogeographic compilations and thermal preferences determined by comparison to spring-summer $\mathrm{Mg} / \mathrm{Ca}$ temperatures of co-occurring planktonic foraminifera Globigerina bulloides (De Schepper et al., 2011). The paleoenvironmental interpretations are principally based on a few common to abundant taxa, and index-species with relatively well-constrained (paleo)ecological preferences. Appendix B provides a summary of the biogeography of extant and extinct species that have been utilized for interpretation (Fig. 3). The only ecological group erected is Protoperidinium spp., which includes the round brown cysts and all species of the genera Trinovantedinium, Barssidinium, Sumatradinium, Selenopemphix, Lejeunecysta, Xandarodinium, Brigantedinium and Cristadinium, as there is a positive correlation between cysts of heterotrophic taxa in Quaternary to recent sediments and productivity (e.g. Devillers and de Vernal, 2000; Reichart and Brinkhuis, 2003; Radi and de Vernal, 2008). Moreover, a number of protoperidinioid species prefer diatoms as a specific food source (e.g. Jacobson and Anderson, 1986). Their heterotrophic affinity has been proven by fluorescence microscopy since the absence of autofluorescence in recent dinocysts has been related to a heterotrophic feeding strategy (Brenner and Biebow, 2001; Appendix A).

For interpretation of the diversity indices, it has to be considered that diversity of marine phytoplankton is generally lowest at the poles and higher at lower latitudes (Barton et al., 2010). Moreover, on global scale, dinocyst diversity is positively correlated with annual mean sea-surface temperature but only marginally with nutrient concentration (Chen et al., 2011), and thus dinocyst diversity may provide independent estimates for relative temperature changes. In surface samples from the modern Nordic Seas, it has also been shown that species diversity is higher in the comparatively temperate Norwegian Sea when compared to the cold-water influenced Iceland Sea and East Greenland margin (Matthiessen, 1995); and in the Pliocene of the Labrador Sea, diverse dinocyst assemblages correspond to

Plate I. All photomicrographs are in bright field illumination. Various magnifications. Max. dia. = maximum diameter.

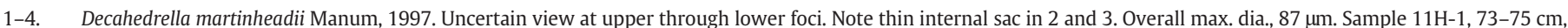
slide $1 ; 050 / 0$.

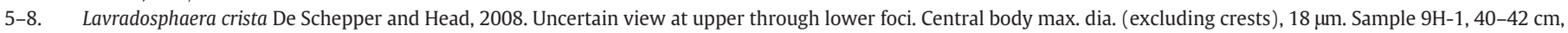
slide $1 ;$ M52/0.

9-12. ?Lavradosphaera sp. 1. Uncertain view at upper through lower foci. Central body length, $29 \mu \mathrm{m}$; width, $16 \mu \mathrm{m}$. Sample $23 \mathrm{H}-6,97.5-99.5 \mathrm{~cm}$, slide 1; 048/3.

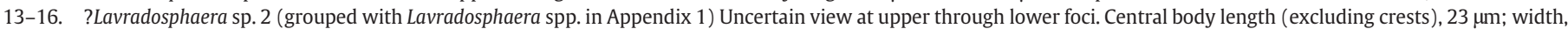
$17 \mu \mathrm{m}$. Sample 16H-2, 91.5-93.5 cm, slide 1; L40/2.

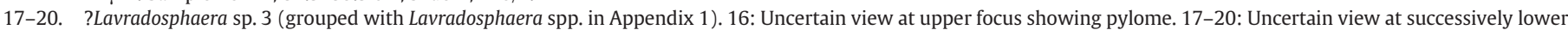
foci. Central body max. dia. (excluding crests), $16 \mu \mathrm{m}$. Sample 23H-6, 97.5-995 cm, slide 1; M43/3. 

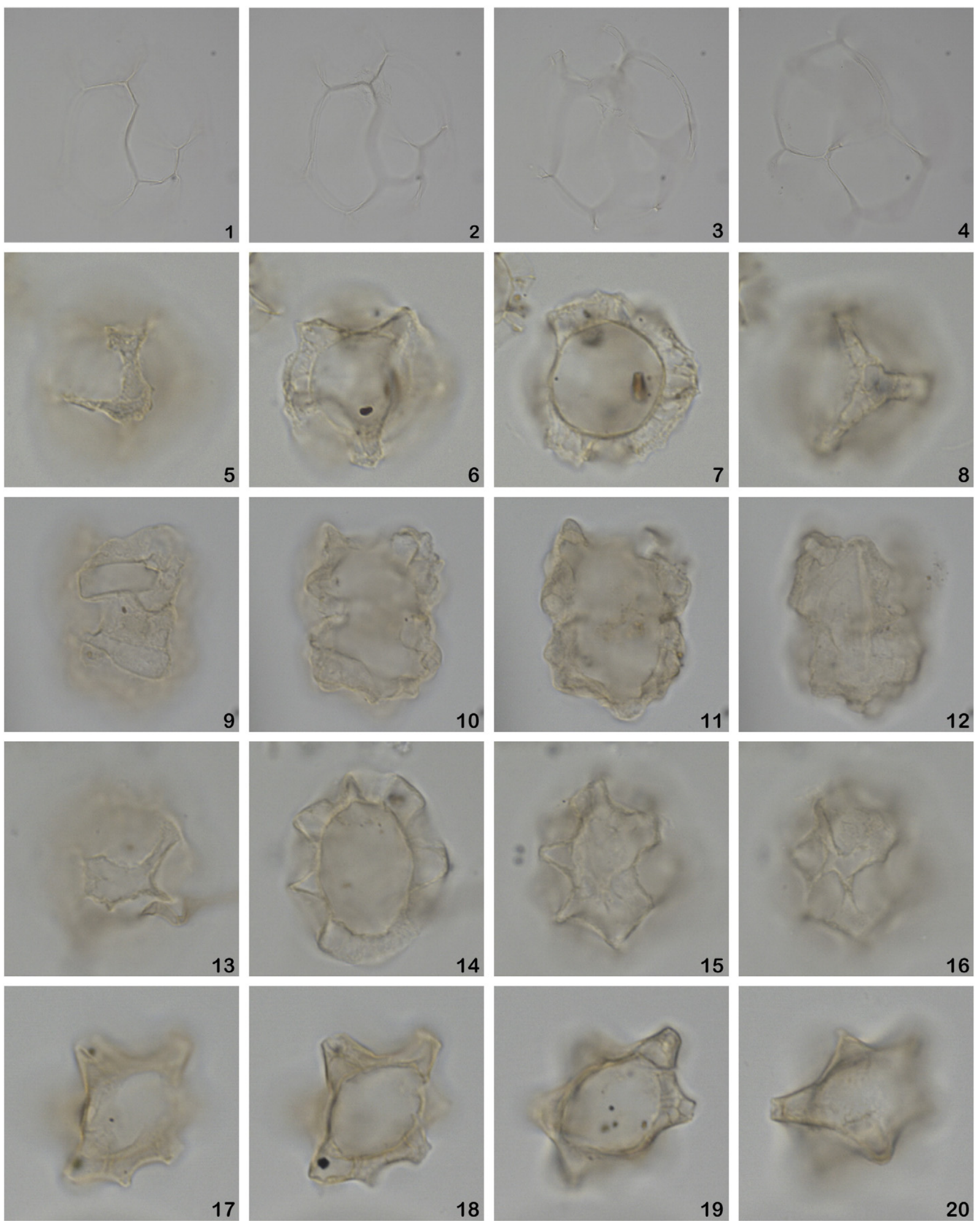


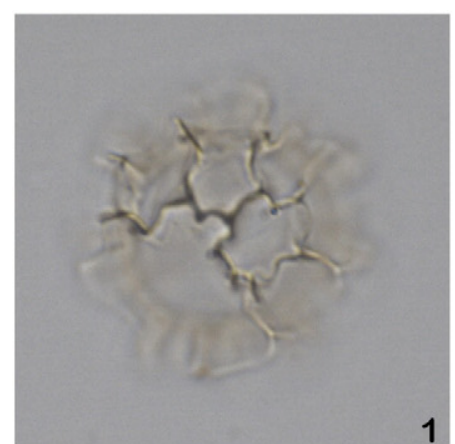

1
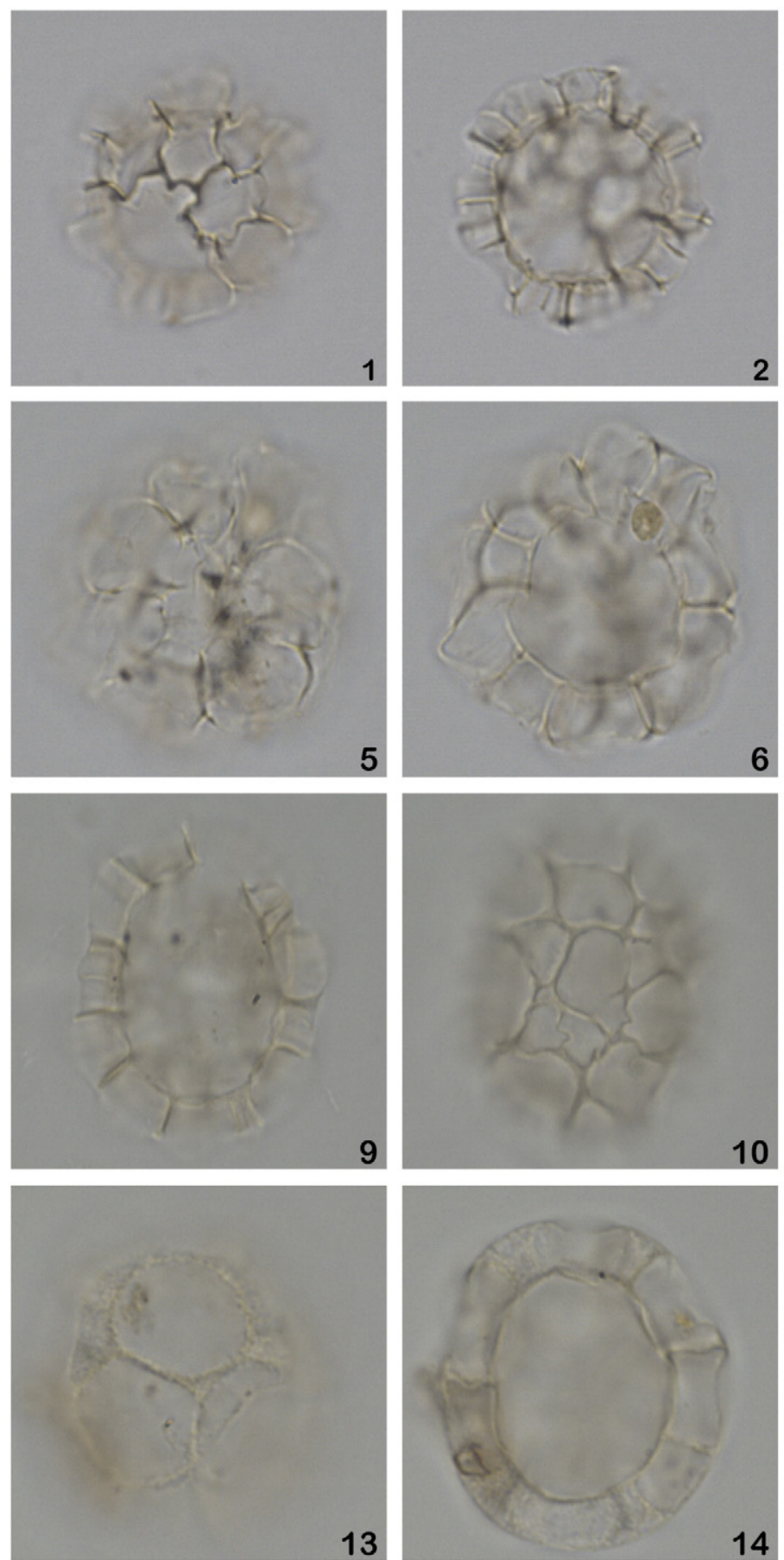

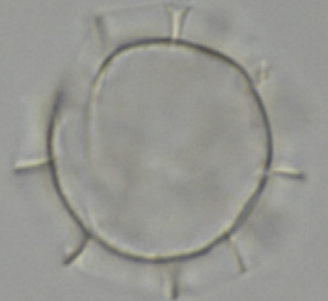

3
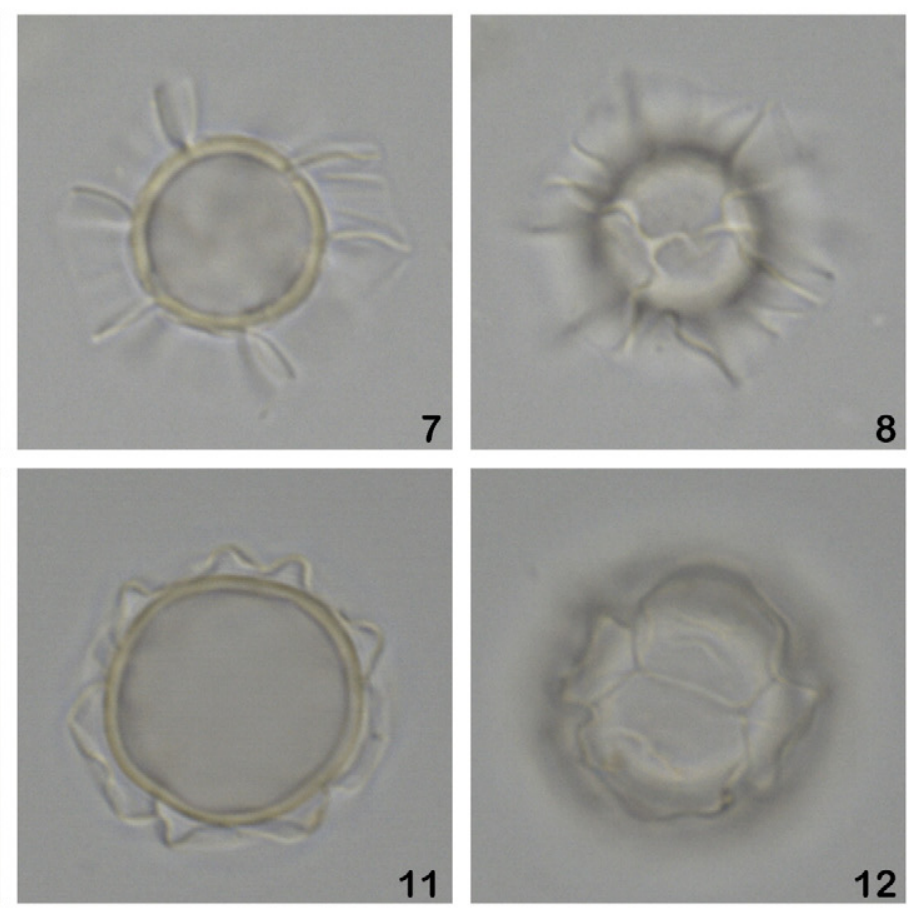

15

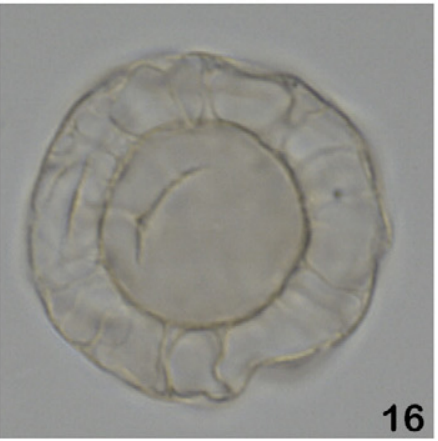

Plate II. All photomicrographs are in bright field illumination. Various magnifications. Max. dia. = maximum diameter.

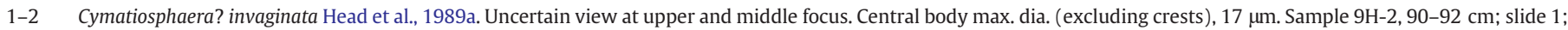
L54/1.

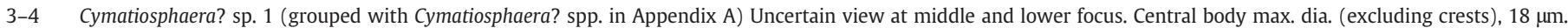
Sample 14H-6, 30-32 cm, slide 1; J37/1.

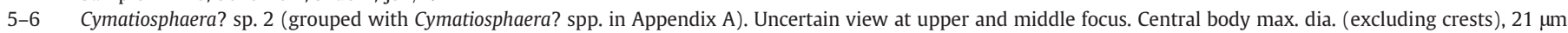
Sample 18H-5, 121-123 cm, slide 1; 051/0.

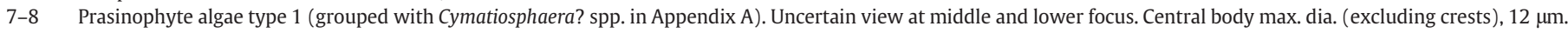
Sample 9H-3, 41-43 cm, slide 1; G44.

9-10 Acritarch sp. 1. Uncertain view at middle and lower focus. Central body length, $29 \mu \mathrm{m}$; width $20 \mu \mathrm{m}$ (both excluding crests). Sample $16 \mathrm{H}-6$, $20-22 \mathrm{~cm}$, slide 1 ; N49/3.

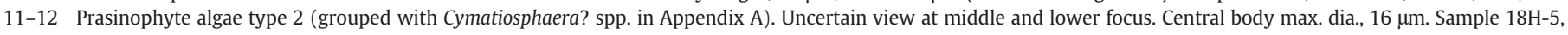
$121-123 \mathrm{~cm}$, slide $1 ; \mathrm{H} 45 / 2$.

13-14 Acritarch sp. 2. Uncertain view at upper and middle focus. Central body length, $23 \mu \mathrm{m}$; width, $18 \mu \mathrm{m}$ (both excluding crests). Sample $13 \mathrm{H}-5,12-14 \mathrm{~cm}$, slide 1 ; H48/2.

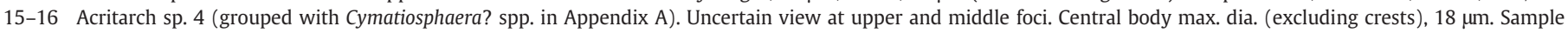
$13 \mathrm{H}-5,12-14 \mathrm{~cm}$, slide $1 ; \mathrm{K} 52 / 3$. 
interglacial stages while low diversity assemblages correlate with glacial periods (de Vernal and Mudie, 1989b).

\subsection{Reworked dinocysts}

Reworking of Neogene sediments is of minor importance as well-known stratigraphic marker species occur only rarely above their range tops (Schreck et al., 2012). Limited reworking of pre-Neogene material constantly occurs in Langhian and Serravallian sediments but only sporadically above that interval. However, the number of reworked dinocysts never exceeds $1 \%$ of the assemblage. Only Sample 6H-3, 82-84 cm (49.1 mbsf, 2.6 Ma) contains abundant reworked dinocysts. Reworked Paleogene species include Deflandrea phosphoritica, Svalbardella spp., Eatonicysta ursulae, Enneadocysta spp., Homotryblium spp., Oligosphaeridium spp. and Wetziella spp.

\subsection{Acritarchs}

Acritarchs constitute a significant part of the palynomorph assemblage throughout most of the analyzed interval and partly even outnumber dinocysts (Fig. 2, Appendix A). For samples with less than 20 acritarchs counted relative abundances have not been calculated to circumvent artificial abundance peaks. This diverse complex has been roughly subdivided into five distinctive morphological groups.

\subsubsection{Decahedrella martinheadii (Plate I, 1-4)}

This morphologically characteristic acritarch has a restricted range in Hole 907A. It first occurs at $10.5 \mathrm{Ma}$, and is continuously present until its last occurrence at 6.3 Ma (Fig. 2; Schreck et al., 2012). It reveals high relative abundances from 9.9 to $8.9 \mathrm{Ma}$, but constitutes up to $90 \%$ of the palynomorph assemblage between 6.7 and 6.5 Ma.

3.4.1.1. Ecology. This species is endemic for the high northern latitudes and considered a cool-temperate to cold-water oceanic species (Manum, 1997; Matthiessen et al., 2009).

\subsubsection{Prasinophyta (Plate I, 5-20; Plate II, 1-16)}

This group is mainly composed of species that could be assigned to the genera Cymatiosphaera and Lavradosphaera (mainly Cymatiosphaera? invaginata and Lavradosphaera crista). Other specimens broadly resemble different pterosphaeridiaceaen and cymatiosphaeridiaceaen species, but have not been determined to species level. Prasinophytes are common between 14.5 and $12.6 \mathrm{Ma}$, but most abundant at $12.5 \mathrm{Ma}$, and between 10.9 and $10.1 \mathrm{Ma}$. Cymatiosphaera? invaginata and L. crista exclusively dominate the acritarch assemblage between 5 and $4.5 \mathrm{Ma}$ (Fig. 2).

3.4.2.1. Ecology. Fossil prasinophytes are just as cosmopolitan as their modern relatives (Fensome et al., 1990; Guy-Ohlson, 1996), but are known to be important elements of modern phytoplankton in high latitude seas (Tyson, 1995 and references therein). Indeed, exceptionally light $\delta^{13} \mathrm{C}$ values of fossil phycomata suggest a relation to low temperature and reduced salinity (Prauss and Riegel, 1989), and a general association or affinity with cold waters has been suggested, largely based on the high paleo-latitude or glacial associations of prasinophyte-rich facies (Tyson, 1995). In modern and Quaternary sediments, prasinophytes (in particular Cymatiosphaera species) are often associated with less saline and/or cool surface water and a stratified water column (Wall et al., 1973; Wall and Dale, 1974; Tappan, 1980; Sorrel et al., 2006). The common occurrence in early Oligocene glaciomarine sediments from the Antarctic continental margin (Hannah et al., 2000) supports an affinity for cooler, presumably ice-covered waters. The (paleo)biogeographic distribution of the genus Lavradosphaera likely suggests an affinity for cool-temperate waters (De Schepper and Head, in press).

\subsubsection{Acanthomorphitic acritarchs (Plate III, 1-12)}

In the lower part of the hole this group is mainly composed of 2 morphotypes that may be attributed to the genus Micrhystridium, complemented by Nannobarbophora gedlii. This morphological complex dominates the acritarch assemblage during the Middle to early Late Miocene, actually reaching more than $50 \%$ of the whole palynomorph assemblage between 12.5 and $12.0 \mathrm{Ma}$ (Fig. 2), but disappeared abruptly at $\sim 10.8 \mathrm{Ma}$. Acanthomorphitic acritarchs sporadically recorded above this stratigraphic level broadly resemble the cyst of the dinoflagellate Pentapharsodinium dalei but an unambiguous assignment could not be made. However, the latter complex only plays a subordinate role.

3.4.3.1. Ecology. The ecology of this group is yet poorly constrained (Strother, 1996) since our knowledge is mainly based on occurrences in Palaeozoic and Mesozoic deposits (Batten, 1996). The Neogene Nannobarbophora gedlii is associated with warm-water conditions (Head, 2003) as is the genus. The ecology of Micrhystridium spp. is unknown, but Jiménez-Moreno et al. (2006) recorded abundant Micrhystridium spp. in the earliest Serravallian of central Europe probably indicating a more temperate distribution of these spinous forms. Common Micrhystridium spp. have also been reported from the Middle Miocene of McMurdo Sound (Hannah et al., 1998, 2000) but figured specimen are more similar to the dinocyst species Islandinium and Echinidinium than to the acanthomorphs observed during this study. Thus, this acritarch group may rather have an affinity to warmer waters.

\subsubsection{Sphaeromorphitic acritarchs (Plate III, 13-20)}

This group comprises discoidal to spherical forms similar to the extant genera Halosphaera and Leiosphaeridia. Due to the lack of distinguishing features, unfavorable orientation and recurrent folding these taxa could not be determined to genus level. Thus, these specimens may belong to various genera/species but are here treated as sphaeromorphitic acritarchs although e.g. Leiosphaeridia has been recently assigned to the prasinophyte algae (Guy-Ohlson, 1996). They only occur sporadically throughout but are common at $13 \mathrm{Ma}$, 11.5 Ma, and between 5.5 and 4.5 Ma (Fig. 2).

3.4.4.1. Ecology. In modern sediments of high latitude environments, spherical forms such as Leiosphaeridia spp. occur frequently in vicinity to sea ice margins (Mudie et al., 1990; Mudie, 1992). By analogy, they have been associated with colder and less saline conditions, sea ice, and/or the inflow of Arctic waters in the Late Miocene through Pliocene of the Subarctic North Atlantic (e.g. Mudie et al., 1990). The dominance of Leiosphaeridia spp. in early Miocene glaciomarine sediments from the Antarctic continental margin (Hannah et al., 2000) supports this interpretation. In pre-Neogene high latitude deposits Leiosphaeridia spp. is often associated with increased nutrient availability either related to upwelling (Firth and Clark, 1998) or probably stratified surface waters (e.g. Bremer et al., 2004).

\subsubsection{Undifferentiated acritarchs}

This group encloses morphotypes, which could not be attributed to one of the other groups due to diverging morphology and/or preservational reasons.

3.4.5.1. Ecology. The uncertain taxonomy prevents the assignment of ecological preferences.

\subsection{The $U^{K^{\prime}}{ }_{37}$ sea surface temperature record}

Except the lowermost sample (23H-6, 97.5-99.5 cm, $215.27 \mathrm{mbsf}$ ), all samples analyzed yielded alkenones to allow the application of the $U^{K^{\prime}}{ }_{37}$ index to calculate SSTs (Table 1, Fig. 2). Although core top samples close to our study site yielded $U^{K^{\prime}}{ }_{37}$ values for a given SST that fall within the Müller et al. (1998) 99\% data envelope (Bendle and Rosell-Melé, 2004) we acknowledge that absolute temperatures should not be 
taken at face value. The results from Site 907 indicate conditions considerably warmer than at present day (mean annual temperature $\sim 2.5^{\circ} \mathrm{C}$ ) with SSTs as high as $20^{\circ} \mathrm{C}$ at around 13.5 Ma decreasing towards $8{ }^{\circ} \mathrm{C}$ by around $3 \mathrm{Ma}$ (Fig. 2). Further comparisons are hampered by the scarcity of high northern latitude Neogene SST time series, which all focus on the Plio-Pleistocene (e.g. Robinson, 2009; Lawrence et al., 2009, 2010; Naafs et al., 2010), or pre-Neogene epochs (Weller and Stein, 2008).

\section{Discussion}

Superimposed on the general long-term trend from a highly diverse Middle Miocene palynomorph assemblage towards the impoverished assemblages of the Late Pliocene significant fluctuations in abundance and composition have been observed (Figs. 2 and 3). Some of these fluctuations are apparently linked to short-term Mi-events and other paleoenvironmental events as shown in Fig. 4. The palynological data are here complemented with alkenone SSTs and TOC data (Fig. 2) to characterize and discuss the paleoenvironmental evolution of the Iceland Sea between 14.5 and $2.5 \mathrm{Ma}$.

\subsection{The Middle Miocene transition (14.5-13.0 Ma)}

Sedimentation at Site 907 commenced shortly after the MCO and high palynomorph concentration corroborates a high primary productivity (Zonneveld et al., 2010), which has also been inferred from abundant diatoms and their resting spores after $14 \mathrm{Ma}$ (Stabell and Koç, 1996). However, as protoperidiniacean dinocysts are usually abundant in upwelling areas (e.g. Reichart and Brinkhuis, 2003; Holzwarth et al., 2010), their low abundance during this interval in the Iceland Sea does not support substantial upwelling as suggested by Stabell and Koç (1996). Since selective degradation is excluded due to light to dark brown colors of cyst walls and no evidence of oxidative damage of Barssidinium and Cristadinium specimens encountered, the high paleoproductivity likely resulted from increased nutrient input due to enhanced chemical weathering during a much warmer and humid climate (Wan et al., 2009; Ma et al., 2011; Pound et al., 2012). The significant decline in the Shannon-Wiener index towards lowest Miocene values at $\sim 13.7$ Ma likely depicts the impact of subsequent cooling during the MMCT (14.2-13.7 Ma, Shevenell et al., 2004). As species richness appears to be rather constant across this interval, the decline in the Shannon-Wiener index reflects a drastic shift of species proportions within the dinocyst assemblage, which may be caused by the increase of presumably opportunistic species (i.e. the B. micropapillata complex) during times of ecosystem perturbation. However, the richness exhibits two transient minima centered at $\sim 14.2$ and $\sim 13.7 \mathrm{Ma}$, which may denote the two-step character of the MMCT (Mi-3a/b, Miller and Mountain, 1996; Abels et al., 2005; Mourik et al., 2011). A short-term decrease in acritarch concentration, but a relative shift in assemblage composition from more warm-temperate acanthomorphitic acritarchs ( $N$. gedlii, Micrhystridium spp.) to prasinophytes characterizes both steps. The MMCT is also reflected by a decline in B. sphaerica, L. truncatum and Palaeocystodinium spp. accompanied by the first occurrence of the cool-water species $H$. tectata at $\sim 14.2 \mathrm{Ma}$ (temperature range c. $9-17{ }^{\circ} \mathrm{C}$, De Schepper et al., 2011). Batiacasphaera hirsuta and the B. micropapillata complex both increase during the early phase of this transition followed by a significant drop at $\sim 14.1$ and $\sim 14.2$ Ma respectively. The latter is common in the Middle to Late Miocene of the high northern latitudes including the Arctic Ocean, and is considered a cool- to warm-temperate species complex, which may sustain some sea ice cover (Schreck and Matthiessen, in press). Its drastic increase at 13.9 Ma thus suggests the establishment of somewhat cooler conditions, but the occurrence of sea ice in the Iceland Sea during the MMCT as reported from Fram Strait (Knies and Gaina, 2008; Thiede et al., 2011) remains speculative because IRD has only been studied from $~ 8 \mathrm{Ma}$ (Fronval and Jansen, 1996). Nonetheless, the low abundance/absence of (sub)tropical Impagidinium species (e.g. I. paradoxum, I. patulum, and I. strialatum), large gonyaulacoids and species with expanded wall coverings (e.g. Hystrichosphaeropsis pontiana, Hystrichosphaeropsis obscura, Hystrichokolpoma rigaudiae, Lingulodinium machaerophorum, Melitasphaeridium choanophorum, Tuberculodinium vancampoae, Dapsilidinium pseudocolligerum, and Invertocysta spp.) suggest colder surface waters than in the Norwegian Sea and other North Atlantic sites where these taxa dominate coeval assemblages (Harland, 1979; Costa and Downie, 1979; Mudie, 1987; Manum et al., 1989; see Mudie et al., 1990 for discussion). These taxa are also absent from Baffin Bay (Head et al., 1989c), which might be related to the onset of cooler conditions as inferred from the drop in accumulation rates of terrigenous organic carbon around $14.5 \mathrm{Ma}$ (Stein, 1991, 2008).

The cooler surface waters in the Iceland Sea than in the Norwegian Sea may be attributed to enhanced exchange of water masses with the Arctic Ocean and the Nordic Seas since 14 Ma (Jakobsson et al., 2007). As the Transpolar Drift has been active in the past $15 \mathrm{Ma}$ (Haley et al., 2008), the opening of the Fram Strait led to the establishment of a modern-like ice drift pattern with export from the Arctic Ocean into the western Nordic Seas (Fig. 4; Knies and Gaina, 2008), most likely via a proto-East Greenland Current (EGC). This presumably resulted in a temperature gradient across the Nordic Seas as early as the Middle Miocene (cf. Fronval and Jansen, 1996), supported by differences in dinocyst assemblages. In concert with the proposed onset of a Norwegian-Atlantic Current precursor (Henrich et al., 1989), this may point towards the initiation of a proto-thermohaline circulation in the Nordic Seas around this time as also indicated by a prominent switch from biosiliceous to carbonate-rich sedimentation on Vøring Plateau (Bohrmann et al., 1990; Cortese et al., 2004). However, paleobotanical studies on Iceland revealed that a land bridge (i.e. a partly subaerially exposed GSR) between Europe and Greenland must have

\footnotetext{
Plate III. All photomicrographs are in bright field illumination. Various magnifications. Max. dia. = maximum diameter.
}

1-2. ?Micrhystridium sp. 1. Uncertain view at upper and middle focus. Central body length, $23 \mu \mathrm{m}$; process length, $10 \mu \mathrm{m}$. Sample $16 \mathrm{H}-2,91.5-93.5 \mathrm{~cm}$, slide 1 ; N48/3.

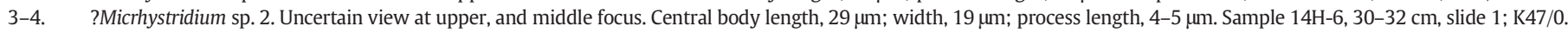

5. ?Micrhystridium sp. 1. Uncertain view at mid focus. Central body length, $24 \mu \mathrm{m}$; process length, $9 \mu \mathrm{m}$. Sample $16 \mathrm{H}-2$, $91.5-93.5 \mathrm{~cm}$, slide 1 ; L38/2.

6. ?Impletosphaeridium sp. Uncertain view at mid focus. Central body length, $36 \mu \mathrm{m}$; width, $23 \mu \mathrm{m}$; process length, $10 \mu \mathrm{m}$. Sample $23 \mathrm{H}-6$, $97.5-99.5 \mathrm{~cm}$, slide 1 ; $\mathrm{S} 41 / 1$.

7-8. ?Micrhystridium sp. 2. Uncertain view at upper, and middle focus. Central body length, $21 \mu \mathrm{m} ;$ process length, $4 \mu \mathrm{m}$. Sample $14 \mathrm{H}-6,10-12 \mathrm{~cm}$, slide 1 ; P51/0.

9-12. Nannobarbophora gedlii Head, 2003.

9-10. Uncertain view at middle, and slightly lower focus. Sample 23H-6, 97.5-99.5 cm; slide 1; N40/1.

11-12. Uncertain view at upper, and middle focus. Sample $13 \mathrm{H}-5,12-14 \mathrm{~cm}$, slide $1 ; \mathrm{D} 47 / 3$.

13-16. Sphaeromorphitic acritarch type 1.

13-14. Uncertain view at middle and lower focus showing smooth wall surface. Central body max. dia., 33 $\mu$ m. Sample 9H-1, 40-42 cm, slide 1; C39/3.

15. Uncertain view in mid-focus. Central body max. dia., $39 \mu \mathrm{m}$. Sample 9H-7, 40-42 cm, slide 1; E53/0.

16. Uncertain view in mid-focus. Central body max. dia., $30 \mu \mathrm{m}$. Sample 9H-2, 90-92 cm, slide 1; D55/4

17-19. Sphaeromorphitic acritarch type 2.

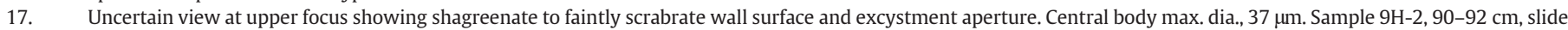
$1 ; \mathrm{E} 55 / 1$.

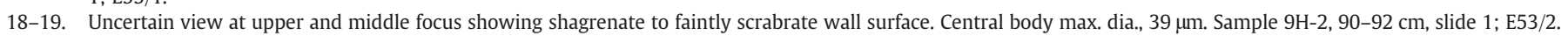

20. Sphaeromorphitic acritarch type 3. Uncertain view at mid-focus. Central body max. dia., 53 mm. Sample 9H-2, 90-92 cm, slide 1; D51/0. 

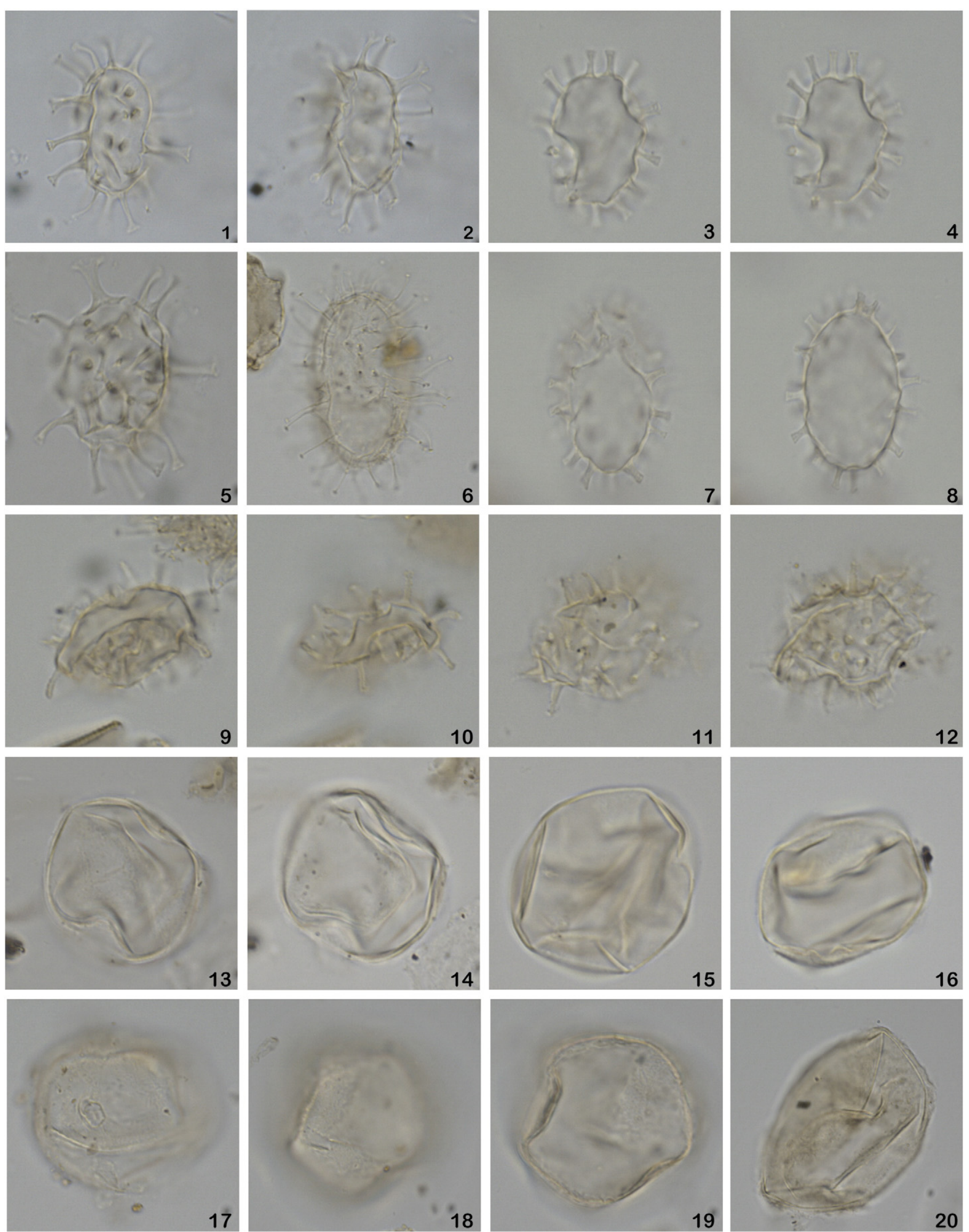
Table 1

Alkenone data from Hole 907A.

\begin{tabular}{|c|c|c|c|c|}
\hline Core, section, interval & Depth & Age & & SST \\
\hline$(\mathrm{cm})$ & (mbsf) & (Ma) & $\mathrm{UK}^{\prime} 37$ & $\left({ }^{\circ} \mathrm{C}\right)$ \\
\hline $7 \mathrm{H}-4,102-104$ & 60.32 & 3.16 & 0.325 & 8.5 \\
\hline $9 \mathrm{H}-2,90-92$ & 76.20 & 4.74 & 0.436 & 11.9 \\
\hline $10 \mathrm{H}-3,90-92$ & 87.20 & 5.80 & 0.278 & 7.1 \\
\hline $11 \mathrm{H}-3,117.5-119.5$ & 96.98 & 6.85 & 0.443 & 12.1 \\
\hline $11 \mathrm{H}-6,77-79$ & 101.07 & 7.72 & 0.550 & 15.3 \\
\hline $12 \mathrm{H}-4,111.5-113.5$ & 107.92 & 9.17 & 0.545 & 15.2 \\
\hline $13 \mathrm{H}-6,20-22$ & 119.50 & 10.44 & 0.643 & 18.1 \\
\hline $16 \mathrm{H}-3,42.5-44.5$ & 143.72 & 12.21 & 0.500 & 13.8 \\
\hline $19 \mathrm{H}-1,34-36$ & 169.14 & 13.39 & 0.718 & 20.4 \\
\hline $23 \mathrm{H}-6,97.5-99.5$ & 215.27 & 14.33 & - & - \\
\hline
\end{tabular}

been present (Denk et al., 2011; Fig. 4) restricting the water mass exchange with the North Atlantic.

A brief ( $500 \mathrm{kyr})$ warming is indicated subsequent to Mi-3b by an increased Shannon-Wiener index, recurrent Palaeocystodinium spp., a single peak of thermophilic Barssidinium graminosum (not shown), and a significant increase in acanthomorphitic acritarchs. The rare but continuous occurrence of Tectatodinium pellitum indicates summer SSTs $>15-25{ }^{\circ} \mathrm{C}$ (De Schepper et al., 2011) consistent with our reconstructed mean annual SST of $20{ }^{\circ} \mathrm{C}$ at $13.4 \mathrm{Ma}$ (Fig. 2). The observed warming of surface waters may have resulted from temporary westward deflection of warmer North Atlantic waters into the Iceland Sea.

The highest persistent occurrence (HPO) of the warm water species T. pellitum, and subsequent peaks of typical high latitude species such as N. labyrinthus, $H$. tectata, I. pallidum, I. cf. pacificum and C. irregulare (Fig. 3) indicate iterative cooling presumably associated with the Miocene isotope event Mi-4 (13.2-13.0 Ma, Westerhold et al., 2005). Likewise the shift that occurred across the MMCT, a pronounced minimum in the $B$. micropapillata complex is accompanied by a decline in B. sphaerica and B. hirsuta, but now co-occurs with very abundant $N$. labyrinthus. The minimum in acanthomorphitic acritarchs, which is similar to that observed during Mi-3a and b, is coeval with an increase in sphaeromorphitic acritarchs (Fig. 2), which, together with increasing $N$. labyrinthus and I. pallidum, may evince first sea ice reaching the Iceland Sea. Impagidinium pallidum has been frequently considered an indicator for cold surface water conditions and a variable range of sea ice cover (e.g. Rochon et al., 1999; de Vernal et al., 2001; Zonneveld et

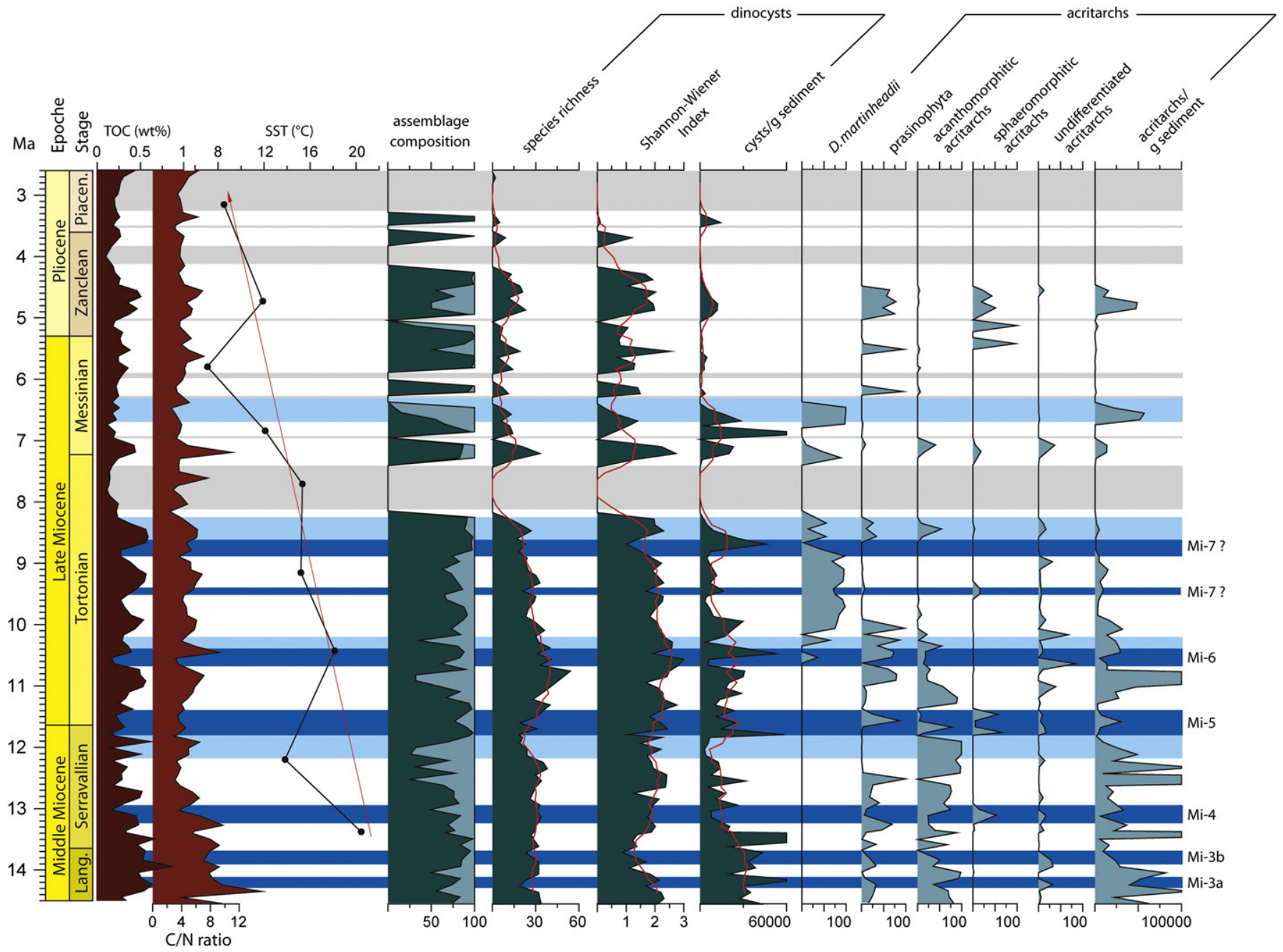

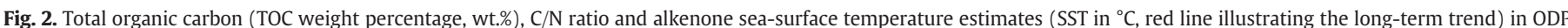

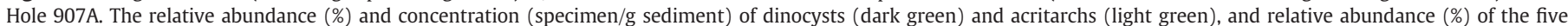

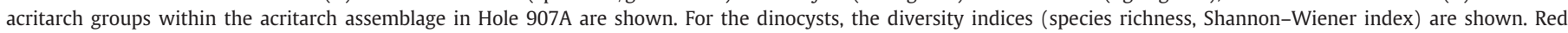

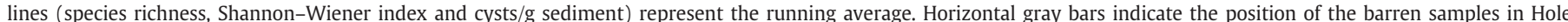

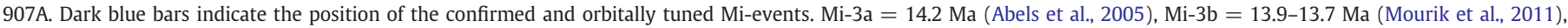

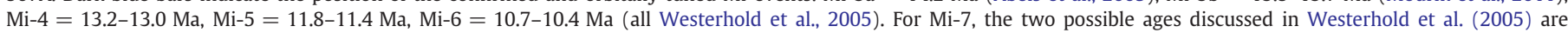
shown. Light blue bars indicate additional cooling phases identified in Hole 907A. 


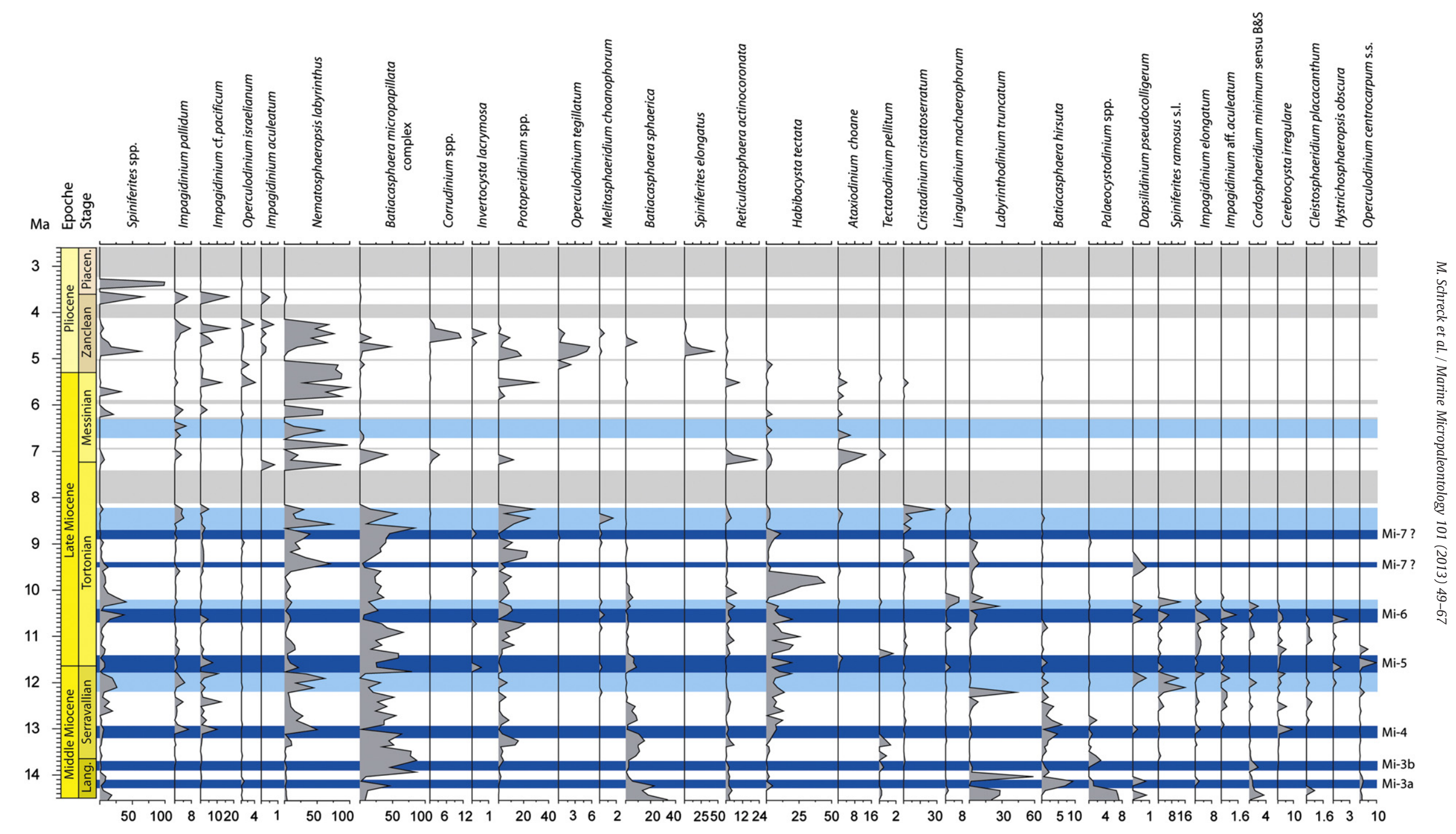

Fig. 3. Detailed diagram showing relative percentages (\% out of the total sum of dinocysts counted) of dinocyst species in Hole 907A used for paleoenvironmental interpretation. For color coding of horizontal bars see Fig. 2 . 
Table 2

List of dinocyst datums associated with the three disappearance events. $\mathrm{HO}=$ highest occurrence, $\mathrm{HCO}=$ highest common occurrence, $\mathrm{HPO}=$ highest persistent occurrence. For stratigraphic ranges of species not shown in Fig. 3 see Appendix A.

\begin{tabular}{ccll}
\hline & Age & Event & Species \\
\hline Disappearance event I & 10.6 & HCO & Hystrichosphaeropsis obscura \\
(10.6-10.2 Ma) & 10.6 & HO & Cleistosphaeridium placacanthum \\
& 10.5 & HO & Spiniferites sp. B \\
& 10.4 & HO & Cerebrocysta irregulare \\
& 10.4 & HO & Cordosphaeridium minimum \\
& 10.4 & HO & Impagidinium sp. A \\
& 10.4 & HO & Operculodinium giganteum \\
& 10.4 & HPO & Selenopemphix brevispinosa \\
& 10.2 & HO & Impagidinium aff. aculeatum \\
Disappearance event II & 10.2 & HO & Impagidinium elongatum \\
& 9.0 & HO & Dapsilidinium pseudocolligerum \\
& 8.9 & HO & Palaeocystodinium spp. \\
& 8.8 & HO & Hystrichosphaeropsis obscura \\
& 8.8 & HO & Spiniferites sp. A \\
& 8.5 & HPO & Selenopemphix nephroides \\
& 8.4 & HPO & Melitasphaeridium choanophorum \\
& 8.4 & HO & Batiacasphaera hirsuta \\
& 8.4 & HO & Labyrinthodinium truncatum \\
& 8.4 & HO & Operculodinium piaseckii \\
Disappearance event III & 8.4 & HO & Selenopemphix brevispinosa \\
& 8.3 & HCO & Cristadinium cristatoserratum \\
& 8.3 & HO & Lingulodinium machaerophorum \\
& 4.5 & HO & Corrudinium? labradori \\
& 4.5 & HCO & Batiacasphaera micropapillata \\
& 4.5 & HO & Batiacasphaera sphaerica \\
& 4.5 & HO & Corrudinium devernaliae \\
& 4.5 & HO & Invertocysta lacrymosa \\
& 4.5 & HO & Melitasphaeridium choanophorum \\
& 4.5 & HO & Pyxidinopsis vesiculata \\
& 4.5 & HO & Operculodinium? eirikianum \\
& 4.5 & HO & Operculodinium tegillatum \\
& 4.5 & HO & Reticulatosphaera actinocoronata \\
& 4.3 & HO & Corrudinium harlandii \\
& 4.3 & HO & Spiniferites elongatus \\
& & & \\
& & \\
& & & \\
& & & \\
& &
\end{tabular}

al., in press), and its common occurrence $(\sim 10 \%)$ has been associated with summer SSTs $<15{ }^{\circ} \mathrm{C}$ (De Schepper et al., 2011). Since H. tectata requires summer SSTs $>9{ }^{\circ} \mathrm{C}$ (De Schepper et al., 2011) and abundances of $N$. labyrinthus $>50 \%$ preponderantly correlate to SSTs $<15{ }^{\circ} \mathrm{C}$ (Bonnet et al., 2012; Zonneveld et al., in press), SSTs might have been in the range of $>9$ to $<15{ }^{\circ} \mathrm{C}$. Today, $N$. labyrinthus is abundant to dominant (40-60\%) in regions where colder, polar waters mix with warmer Atlantic waters (Rochon et al., 1999). As SSTs are still comparatively warm, sea ice likely originated in the Arctic Ocean (St. John, 2008) and has been exported via Fram Strait (Knies and Gaina, 2008) into the western Nordic Seas.

\subsection{Late Middle to early Late Miocene (13.0-10.7 Ma)}

After the incisive changes that occurred across the MMCT and the Mi-4 event, comparatively stable conditions prevailed on the Iceland Plateau after $\sim 13 \mathrm{Ma}$. Concentration indicates dinoflagellate productivity similar to the modern western North Atlantic margin (Rochon et al., 1999), but considerably higher when compared to the modern Iceland Sea (Matthiessen, 1995). A more temperate environment is indicated by the more or less continuous occurrence of Cleistosphaeridium placacanthum, Operculodinium centrocarpum s.s., Impagidinium aff. aculeatum, H. obscura, common Spiniferites ramosus s.l., and very abundant acanthomorphitic acritarchs (Figs. 2 and 3). Consistently, both dinocyst diversity measures show a general increase across the latest Middle through early Late Miocene as a likely response to higher temperature (Chen et al., 2011), only interrupted by a transient decline between 12.3 and $11.6 \mathrm{Ma}$ as also observed in the cyst concentration. Although the age model is well constrained in this interval (Channell et al., 1999), these brief minima, and a coeval minimum of the B. micropapillata complex slightly precede the global Mi-5 cooling
(11.8-11.4 Ma, Westerhold et al., 2005), which might be attributed to insufficient sample resolution. However, these minima coincide with peak abundance of $N$. labyrinthus ( $\geq 50 \%$ ) which suggests SSTs $<15{ }^{\circ} \mathrm{C}$ (Bonnet et al., 2012; Zonneveld et al., in press) and temporary enhanced mixing of Atlantic and polar water (cf. Rochon et al., 1999). Wei (1998) inferred time-equivalent cooling of surface waters along the southeast Greenland margin from calcareous nannofossils, which he attributed to the development of a (proto) EGC. Therefore, the inverse correlation between $N$. labyrinthus and the B. micropapillata complex may indicate cooling, but further studies are needed to test this assumption. Notwithstanding, alterations in the acritarch assemblage resembling those observed during the MMCT occur contemporaneously with Mi-5, whereas the dinocyst diversity and productivity apparently recovers. On continental Iceland, pollen data also suggests that markedly warm conditions persisted at least until the Late Miocene (Denk et al., 2011). These temperate conditions might be related to a generally enhanced inflow of North Atlantic waters into the Nordic Seas as suggested by the renewal of NCW production around 13-12 Ma (Bohrmann et al., 1990; Wright and Miller, 1996; Poore et al., 2006).

\subsection{Glacial inception in the Iceland Sea ( 10.7-10.2 Ma)}

Both diversity measures start to decline within this interval accompanied by the first occurrence of the endemic cold-water acritarch Decahedrella martinheadii (Manum, 1997; Matthiessen et al., 2009) at $\sim 10.5 \mathrm{Ma}$, and a significant cluster of species last occurrences (Table 2, Figs. 2 and 3). The B. micropapillata complex shows a significant minimum as previously observed during Mi-3, Mi-4, and shortly prior to Mi-5 while Impagidinium elongatum, Spiniferites spp. (mainly $S$. ramosus s.l.), and cool-water $H$. tectata, contribute significantly to the dinocyst assemblage. Whereas S. ramosus s.l. is a cosmopolitan species (Zonneveld et al., in press), the occurrence of I. elongatum appears to be restricted to the high northern latitudes (Schreck et al., 2012). In alignment with common to abundant prasinophytes, and the disappearance of Micrhystridium spp. and warm-temperate N. gedlii, this suggest a cooling of surface waters that may correspond to the Mi- 6 event (10.7-10.4 Ma, Westerhold et al., 2005), which primarily reflects an increase in global ice volume (Turco et al., 2001). Indeed, the onset of predominantly siliciclastic deposition (120 mbsf, $10.5 \mathrm{Ma}$ ) and the occurrence of the first dropstone (116.5 mbsf, $10.3 \mathrm{Ma}$ ) at Site 907 (Fig. 4; Shipboard Scientific Party, 1995) prove ice rafting since that time, and suggest a link between observed assemblage changes and the Mi-6 event. Increased bulk accumulation rates at ODP Site 909 supposedly reflect intensification of water mass exchange through Fram Strait (Wolf-Welling et al., 1996; Winkler et al., 2002), which would have resulted in enhanced advection of comparatively cold, low saline, and presumably ice covered waters into the Iceland Sea, forcing the observed changes in the palynomorph assemblage. The increased advection of colder waters may have triggered the coeval collapse in accumulation of Chaetoceros resting spores reflecting a diminished diatom production (Stabell and Koç, 1996).

Benthic $\delta^{18} \mathrm{O}$ values on Vøring Plateau indicate substantial deep water cooling at $\sim 11 \mathrm{Ma}$ (Fronval and Jansen, 1996), and increased circum-Arctic IRD fluxes between 11.0 and 9.5 Ma (Schaeffer and Spiegler, 1986; Thiébault et al., 1989; Wolf and Thiede, 1991; Fronval and Jansen, 1996; Wolf-Welling et al., 1996; Helland and Holmes, 1997; Winkler et al., 2002) prove general cooling in the high northern latitudes. The timing of IRD events broadly corresponds to a major uplift phase on Greenland (Thomson et al., 1999; Japsen et al., 2006) suggesting a pivotal role in establishing the Greenland Ice Sheet during Late Miocene times, when $p \mathrm{CO}_{2}$ stabilized at pre-industrial values (Pagani et al., 1999). Recently, Hegewald and Jokat (2013) showed that substantial relative global sea level fall since the middle Miocene, culminating in a lowstand at about the same time, is even more strongly expressed in the Arctic Ocean, and assumed a relation to the formation of ice sheets on the Northern Hemisphere. 

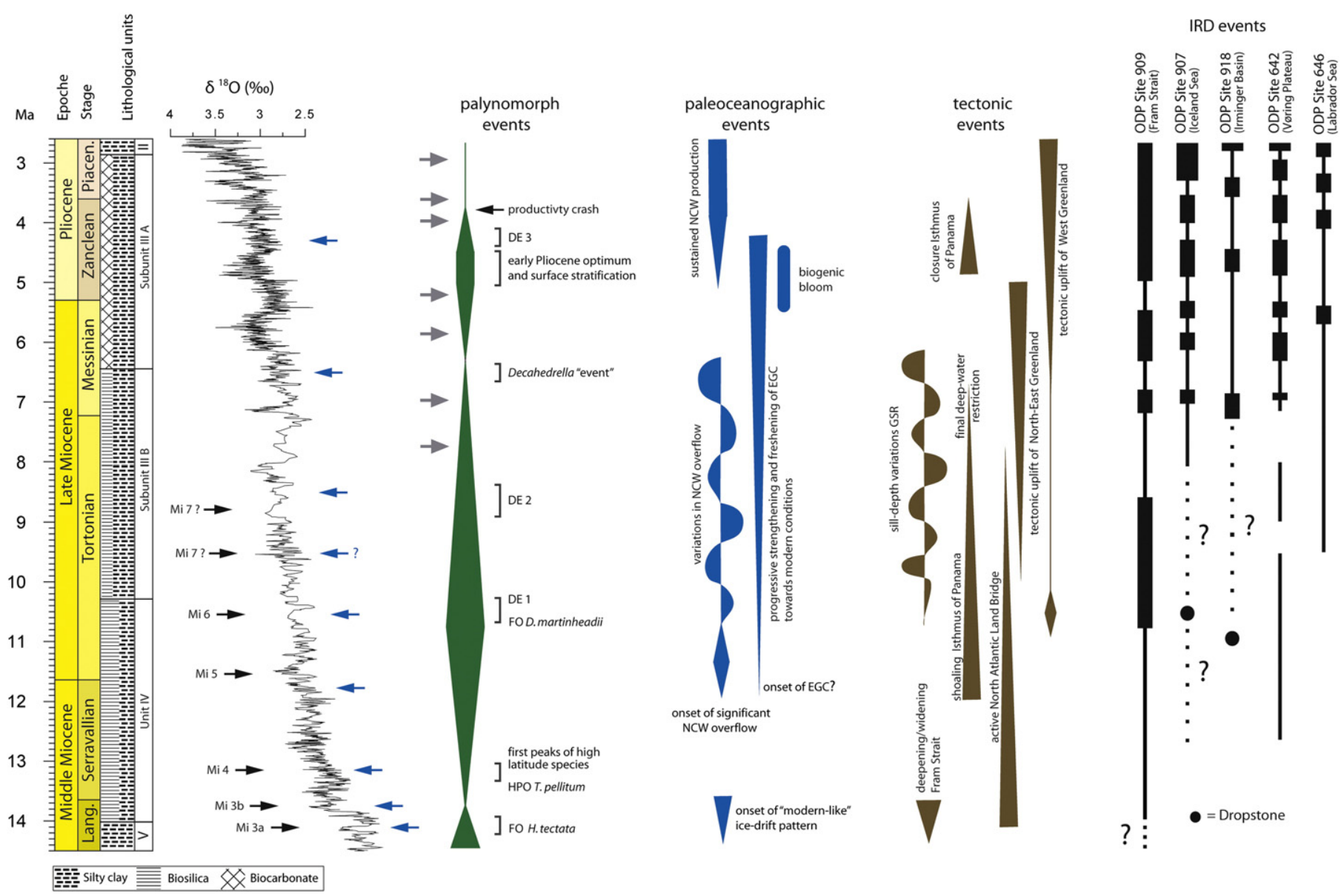

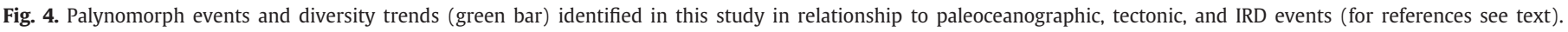

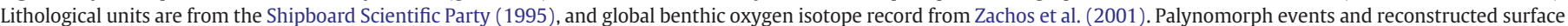

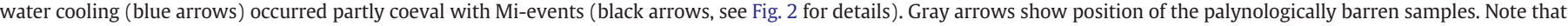

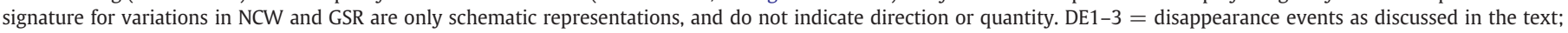
FO = first occurrence; HPO = highest persistent occurrence; NCW = Northern Component Water; EGC = East Greenland Current; GSR = Greenland-Scotland Ridge.

A similar cooling at $\sim 10.5$ Ma has been reported not only from northeast North Atlantic ODP Site 982 (Andersson and Jansen, 2003), but also from shallow marine deposits in northwest Europe (Donders et al., 2009). Based on pollen from continental Iceland, Mudie and Helgason (1983) proposed a drastic drop in atmospheric temperature $\left(\sim 10^{\circ} \mathrm{C}\right)$ at around $10 \mathrm{Ma}$, but this magnitude has been recently challenged by Denk et al. (2011) who suggest a more continuous climate deterioration starting around that time. Moreover, such drastic change in atmospheric temperature should have been recorded in the alkenone SST as well, that, instead show only a moderate decrease throughout the Late Miocene (Fig. 2).

\subsection{Late Miocene cooling and variable surface water conditions $(\sim 10.2-6.7 \mathrm{Ma})$}

Subsequently, the prevalence of colder Arctic derived waters in the Iceland Sea is suggested by continuously high abundances of the cold-water acritarch D. martinheadii (Fig. 2), and the gradual decline in both diversity measures indicate progressive Late Miocene cooling. Habibacysta tectata declines drastically after a massive acme ( 9.8 Ma), whereas $N$. labyrinthus and the high northern latitude dinocyst Cristadinium cristatoserratum (Schreck et al., 2012) reveal generally higher abundances. As such high abundance of $H$. tectata occurs within its usual temperature range (De Schepper et al., 2011) other factors such as nutrient availability or salinity changes might have been responsible. However, the temporary influence of warmer, more saline Atlantic waters is indicated by low numbers of prasinophytes and the sporadic occurrence of warm-water species (e.g. Operculodinium israelianum, D. pseudocolligerum, L. machaerophorum, and M. choanophorum). The alternating influence of different source water masses is also shown by large fluctuations of $N$. labyrinthus between 10 and $6.8 \mathrm{Ma}$. At $9.5 \mathrm{Ma}$, increased abundance of $N$. labyrinthus coincides with a minimum in the B. micropapillata complex. Interestingly, such inverse correlation has already been observed during Mi- 4 and slightly prior to Mi- 5 suggesting similar conditions around 9.5-9.4 Ma. Indeed, both diversity measures show a contemporaneous short-lived minimum accompanied by sphaeromorphitic acritarchs, and this timing coincides with the Mi-7 event as proposed by Wright and Miller (1992, $9.45 \mathrm{Ma})$, but its identification in high-resolution benthic $\delta^{18} \mathrm{O}$ records, however, remains uncertain (see Westerhold et al., 2005 for discussion). Notwithstanding, this points towards Arctic water inflow that presumably caused the subsequent disappearance of the warm-water D. pseudocolligerum (Fig. 3). Consequently, the variations in surface waters caused a variable pattern of nutrient availability and paleoproductivity as revealed by contemporaneous changes in Protoperidinium spp. and TOC (Fig. 2). The TOC is predominately of marine origin as shown by $\mathrm{C} / \mathrm{N}$ ratios around 6 (Fig. 2; e.g. Bordovskiy, 1965), although they should be interpreted cautiously due to low TOC contents of $\leq 0.5 \%$ (Stein and Macdonald, 2004). However, diatoms also show a distinctive shift from a continuously high to a more variable abundance pattern around $10 \mathrm{Ma}$ (Stabell and Koç, 1996). Variable surface and deep-water circulation and progressive Late Miocene 
cooling has also been reported from the Norwegian Sea (Bohrmann et al., 1990; Ciesielski and Case, 1989; Locker and Martini, 1989), whereby the former is likely coupled to GSR sill depth variations (Poore et al., 2006). Accordingly, Iceland pollen data suggest an active North Atlantic Land Bridge via a partly subaerial exposed GSR until $\sim 8 \mathrm{Ma}$ (Denk et al., 2011), and thus varying surface and deep-water exchange (Fig. 4). Moreover, moist and cool-temperate conditions continuously established on continental Iceland between 10 and 7-6 Ma (Denk et al., 2005, 2011). The waxing and waning of circum-Arctic ice-sheets as indicated by repetitive IRD events during this time in the Fram Strait (Wolf-Welling et al., 1996), the Vøring Plateau (Jansen and Sjøholm, 1991), Labrador Sea (Wolf and Thiede, 1991) and the Irminger Sea (Schaeffer and Spiegler, 1986; St. John and Krissek, 2002) might have been linked to these variations in ocean circulation.

\subsection{Enhanced cold-water advection into the Iceland Sea ( 9-8.4 Ma)}

Superimposed on the progressive decline in dinocyst diversity last occurrences of some dinocyst species cluster between 9.0 and 8.4 Ma. The disappearance respectively the HPO and HCO of several taxa, including those with warm-water affinity and/or longer stratigraphic ranges elsewhere in lower latitudes (Fig. 3, Table 2, Schreck et al., 2012), common I. pallidum and C. cristatoserratum, and very abundant cold-water acritarch $D$. martinheadii, indicate cooling in the Iceland Sea. This is supported by the coeval occurrence of IRD at Site 907 (Fig. 4; Fronval and Jansen, 1996), and the inverse correlation of $N$. labyrinthus and the B. micropapillata complex at $8.6 \mathrm{Ma}$, the latter already observed in the vicinity of previous cooling events. Despite a high abundance of Protoperidinium spp. between 8.5 and $8.2 \mathrm{Ma}$, which is usually associated with elevated primary productivity (Reichart and Brinkhuis, 2003; Radi and de Vernal, 2008) dinocyst concentration drops significantly at 8.6 Ma. Thus, the abundance of protoperidiniacean taxa (mainly C. cristatoserratum, round brown cysts; Fig. 3, Appendix A) may result from severe sea-surface conditions with sea ice cover (Rochon et al., 1999; Radi and de Vernal, 2008). Coincidentally, Engel (1992) reported a shift to a cold-adapted dinocyst assemblage transported from polar regions to DSDP Site 408, located just south of the Denmark Strait, and $\delta^{18} \mathrm{O}$ data (Aksu and HillaireMarcel, 1989) and changes in the coiling ratio of Neogloboquadrina atlantica (Aksu and Kaminski, 1989) at ODP Site 646 in the Labrador Sea strongly suggest strengthened influence of cold water at this time. Accordingly, the cluster of species last occurrences, HCOs and HPOs, and abundant $D$. martinheadii at Site 907 presumably record the amplification of southward transport of colder Arctic waters via the proto-EGC, and thus its progressive development towards modern conditions. Moreover, Wold (1994) inferred the onset of deep Denmark Strait overflow due to initial formation of the Eirik Drift at the same time, suggesting modern-like conditions of surface and deep-water circulation in the Iceland Sea.

Interestingly, cold-indicative silicoflagellate assemblages from the Vøring Plateau suggest a plunge in temperature at 8.5 Ma (Ciesielski and Case, 1989), as does the strong decrease in SSTs in northwest Europe at $\sim 8.4 \mathrm{Ma}$ (Donders et al., 2009). Moreover, in North Atlantic ODP Site 982 a marked increase in $\delta^{18} \mathrm{O}$ occurs around $9 \mathrm{Ma}$ (Andersson and Jansen, 2003), in North Atlantic ODP Site 904 at 8.7 Ma (Miller et al., 1998), in South Atlantic ODP Site 1085 at $8.8 \mathrm{Ma}$ (Westerhold et al., 2005), and in the global $\delta^{18} \mathrm{O}$ composite between 8.9 and $8.7 \mathrm{Ma}$ (Zachos et al., 2008), which may suggest an alternate timing for the Mi-7 event (see discussion in Westerhold et al., 2005) that broadly correspond to the changes observed in the palynomorph assemblage.

\subsection{The palynologically barren interval (8.1-7.4 Ma)}

The sudden disappearance of marine palynomorphs, as well as pollen and spores (not shown), is apparently not related to sedimentation rate changes, as deposition is low but constant in that part of Hole 907A. Moreover, diatoms are present throughout this interval (Stabell and Koç, 1996; Koç and Scherer, 1996) thus excluding low sedimentation rates as a single cause. However, diatoms were studied at low resolution in this interval ( 3 samples) and no overlap exists when compared to our samples. Hence, sample spacing may partly explain the observed differences. In addition, prolonged exposure to oxygen due to the low sedimentation rates might have played an important role preventing the accumulation of palynomorphs, as it would result in aerobic degradation of organic-walled microfossils (e.g. Zonneveld et al., 2008). However, the reason for this barren interval still remains enigmatic, particularly in context of its restricted temporal extent and the sharp recovery of palynomorph concentration after 7.4 Ma, but may involve circulation changes or increased ventilation in the study area that may be related to the onset of Denmark Strait overflow (Wold, 1994) or final collapse of the North Atlantic land bridge (Denk et al., 2011).

\subsection{The "Decahedrella event" and pronounced cooling (6.7-6.3 Ma)}

A pronounced reorganization of the oceanography in the Iceland Sea starting at $\sim 6.7 \mathrm{Ma}$ is unveiled by a significant acme of the endemic cold-water acritarch D. martinheadii (Fig. 2), succeeded by its abrupt disappearance. Dinocyst concentration drops significantly and species richness reaches lowest Miocene values at $\sim 6.2 \mathrm{Ma}$, suggesting unfavorable conditions for dinoflagellates on the Iceland Plateau. Besides D. martinheadii (up to $90 \%$ of the palynomorph assemblage), only rare $N$. labyrinthus and I. pallidum have been recorded. This acme can be traced across the Iceland and Greenland seas into the Arctic Ocean, but although there is some uncertainty in the exact timing of this event at different sites (see Matthiessen et al., 2009 for discussion) it portrays its supraregional prevalence. The comparable composition of the dinocyst assemblage in the Central Arctic Ocean (Matthiessen et al., 2009) and the Iceland Sea suggest an increased advection of cold waters via the proto-EGC. Contemporaneously increasing IRD fluxes (Fig. 4) in the Iceland Sea, on Vøring Plateau (Fronval and Jansen, 1996), and in Fram Strait (Wolf-Welling et al., 1996), and increased $\delta^{18} \mathrm{O}$ values of planktonic foraminifera suggest a major cooling event in the Nordic Seas between 7 and $6 \mathrm{Ma}$ (Fronval and Jansen, 1996), thus linking the "Decahedrella event" with surface water cooling. As SSTs are still significantly higher than annual mean temperatures today they are probably biased to summer temperatures due to a generally increased seasonality in the Late Miocene as shown by Mosbrugger et al. (2005) for continental Europe. However, the observed cooling significantly precedes the establishment of large-scale glaciations in the Northern Hemisphere (Kleiven et al., 2002). The vegetation changes in the high latitudes (Pound et al., 2012) and particularly the general impoverishment of vegetation on Iceland (Denk et al., 2011) is in agreement with these findings and reveals a cool-temperate climate.

\subsection{The Miocene/Pliocene transition (6.3-5.1 Ma)}

The palynomorph record becomes patchy with low dinocyst diversity, while concentration and thus production is somewhat comparable to the modern Iceland Sea (Matthiessen, 1995; Marret et al., 2004). Where they occur, protoperidiniacean cysts (mainly round brown cysts) do not show evidence for enhanced aerobic degradation, thus the low palynomorph concentration in that interval is likely no preservational artifact but rather represents a general development towards modern sea-surface conditions. On the other hand, the samples barren of palynomorphs (including pollen and spores) within this interval may present a preservational bias. The impoverished dinocyst assemblage is dominated by $N$. labyrinthus with abundances usually associated with mean annual temperatures around $5{ }^{\circ} \mathrm{C}$ in modern surface sediments (Marret and Zonneveld, 2003), which is in accordance with our reconstructed SST of $7{ }^{\circ} \mathrm{C}$ at $5.8 \mathrm{Ma}$ (Fig. 2). The occurrence 
of accessory species such as cool-water $H$. tectata and cool to temperate Ataxiodinium choane (Edwards and Anderle, 1992; Rochon et al., 1999) depicts the prevalence of cold conditions in the Iceland Sea after $\sim 6.3 \mathrm{Ma}$, as also shown for ODP Site 982 just south of the GreenlandScotland Ridge (Hodell et al., 2001). Likewise depleted Arctic-Subarctic assemblages have been reported from the Miocene/Pliocene of the Labrador Sea (Head et al., 1989b; de Vernal and Mudie, 1989b; de Vernal and Mudie, 1992), Davis Strait (Piasecki, 2003), and Baffin Bay (de Vernal and Mudie, 1989a), and a Late Miocene temperature decrease has been inferred for the Norwegian Sea based on silicoflagellates (Locker and Martini, 1989). Abundant prasinophytes (mainly C.? invaginata) and presumably sea ice indicative sphaeromorphitic acritarchs co-occur with significant IRD at $\sim 5.4 \mathrm{Ma}$ (Fronval and Jansen, 1996) and suggest not only colder, but also less saline and probably stratified surface waters between 5.5 and $5.3 \mathrm{Ma}$, a time of major global cooling and intense glaciations (Hodell and Kennett, 1986). However, the co-occurrence of O. israelianum and T. pellitum, which both prefer summer SST $>10{ }^{\circ} \mathrm{C}$ (De Schepper et al., 2011) and are restricted to warm water conditions today, and presumably sea ice indicative acritarchs either implies increased seasonality in the Iceland Sea or sporadic advection of relatively warmer North Atlantic water.

\subsection{Early Pliocene surface stratification and elevated productivity (5.1-4.5 Ma)}

The Early Pliocene is characterized by elevated marine productivity as indicated by an increase in cyst concentration, the common occurrence of Protoperidinium spp., and an increase in TOC, which is presumably of marine origin (Fig. 2). Coeval IRD pulses (Fig. 4; Fronval and Jansen, 1996) indicate freshwater input via melting sea ice/icebergs likely causing surface water stratification as suggested by abundant prasinophytes (C.? invaginata, L. crista; Fig. 2, Appendix A), triggering the productivity increase. Such enhanced Early Pliocene dinocyst productivity has also been observed in the Labrador Sea (de Vernal and Mudie, 1989b) and the Vøring Plateau (Mudie, 1989), and appears to be in concert with the global biogenic bloom (see Cortese et al., 2004 for discussion). Furthermore, common to abundant C.? invaginata in the Labrador Sea (de Vernal and Mudie, 1989b), Davis Strait (Piasecki, 2003) and Baffin Bay (de Vernal and Mudie, 1989a) indicate somewhat similar surface water conditions with temporary freshening and/or stratification on both sides of Greenland presumably related to the waxing and waning of the Greenland Ice Sheet.

Furthermore, the Early Pliocene SST might have been somewhat higher than in the latest Miocene, which agrees with the general consensus of a warm Early Pliocene following a cooler period in the latest Miocene (e.g. Lawrence et al., 2009; Salzmann et al., 2011; Seki et al., 2012). Spiniferites elongatus, a major component of the dinocyst assemblage during this phase, is usually associated with cooltemperate surface waters (Rochon et al., 1999; Zonneveld et al., in press) that may have (seasonally) reduced salinities (Zonneveld et al., in press). However, in recent sediments around Iceland it has highest abundances in areas underlying the comparatively warm Irminger Current (Marret et al., 2004), and off North Norway in areas underlying the Norwegian-Atlantic Current (Matthiessen, 1995). Common S. elongatus has been also recorded during MIS5e from the Vøring Plateau (Van Nieuwenhove et al., 2007) and the Eurasian continental margin (Matthiessen et al., 2001) associated with Atlantic water inflow. The sporadic occurrence of Invertocysta lacrymosa, Impagidinium aculeatum, M. choanophorum, Corrudinium spp., Operculodinium tegillatum, and o. israelianum indeed indicate temporary advection of North Atlantic derived warm water presumably linked to intensified heat transport to the high latitudes since the restriction of the Panama Isthmus (Fig. 4; Haug and Tiedemann, 1998; Butzin et al., 2011).

\subsection{Early Pliocene species turnover (4.5-4.3 Ma)}

Last occurrences of species distinctly cluster between 4.5 and 4.3 Ma (Fig. 3, Table 2), and their higher stratigraphic occurrence in lower latitudes (Schreck et al., 2012) suggests a strong climatic control on this event. This species turnover demonstrates a pronounced adjustment of the Iceland Sea palynomorph assemblage to changing oceanographic conditions prior to the intensification of Northern Hemisphere glaciations. Recent studies (Sarnthein et al., 2009; Verhoeven et al., 2011) indicate the onset of a northward flow of Pacific waters through Bering Strait into the Arctic Ocean at that time caused by the further restriction of the Panama Isthmus, which resulted in a considerably fresher, modern like EGC and the thermal isolation of Greenland (Sarnthein et al., 2009). Thus, this species turnover is the result of both decreasing temperature and salinity, and likely reflects the establishment of the modern EGC.

\subsection{Early through Late Pliocene: productivity crash and/or pronounced deep-water formation (4.2-2.5 Ma)?}

The most distinctive feature of the Pliocene is a crash in palynomorph accumulation at $4.2 \mathrm{Ma}$, which significantly precedes the diatom productivity crash between 3.5 and 3.3 Ma (Stabell and Koç, 1996) and antedates the first major IRD peak at 3.3 Ma that marks the expansion of the Greenland Ice Sheet (Jansen et al., 2000; Kleiven et al., 2002). Thus, sea-surface conditions similar to modern that seriously affected palynomorph productivity have already been established in the Iceland Sea well before the onset of large-scale glaciations on Greenland.

Besides almost mono-specific Spiniferites spp. assemblages at 3.6 Ma, 3.4 Ma and 3.3 Ma all subsequent samples are virtually barren of marine palynomorphs ( $<10$ cysts/sample). Dilution by high input of terrigenous material is an unlikely cause for this barren interval, as it would have affected all microfossil groups. Moreover, as sedimentation rates are fairly constant between 7.0 and $2.5 \mathrm{Ma}(1.5-2.5 \mathrm{~cm} / \mathrm{kyr})$ accumulation of biogenic material must have been altered by processes at the sea surface (e.g. nutrient availability, sea ice cover) or within the deeper waters such as selective degradation and dissolution (Jansen et al., 1996). Species recorded just below this interval (N. labyrinthus, I. pallidum, and S. elongatus) survive harsh conditions with up to 12 months per year sea ice cover (de Vernal et al., 2001; Zonneveld et al., in press) excluding sea ice as a single cause, and nutrient availability might be excluded since diatoms have been constantly recorded in this interval (Stabell and Koç, 1996). Recent studies demonstrate a species-dependent selective aerobic degradation (Zonneveld et al., 2008, 2010), and "Impagidinium and Nematosphaeropsis are clearly more resistant than TOC" (Versteegh et al., 2010, p. 177), but all other dinocyst species degrade considerably faster. However, $N$. labyrinthus and Impagidinium spp. disappear abruptly whereas TOC contents even show a slight increase (Fig. 2). Therefore, post-depositional aerobic degradation due to sinking of well-oxygenated surface waters during times of enhanced deep-water formation probably played a role, but is unlikely the single cause. In addition, sampling might have been biased towards unfavorable conditions, and narrow intervals with abundant palynomorphs might have not been sampled. Nevertheless, this barren interval might indicate increased Pliocene overturning circulation in the Iceland Sea related to the closure of the Panama Isthmus (Haug and Tiedemann, 1998) or a submerged Greenland-Scotland Ridge (Robinson et al., 2011), as also indicated by sustained NCW production during this time (Poore et al., 2006).

\section{Conclusions}

For the interval between 14.5 and $2.5 \mathrm{Ma}$, ODP Hole 907A has been palynologically investigated on $\sim 100 \mathrm{kyr}$ resolution in order to provide new constraints on the Neogene paleoenvironmental evolution of the 
Iceland Sea. In addition, an alkenone based SST record has been constructed to portray its long-term thermal development. In general, our findings are in good accordance with the few Neogene high northern latitude proxy records available highlighting the potential for palynomorph based paleoenvironmental reconstruction.

The Middle Miocene Iceland Sea is characterized by a high marine productivity, and distinctive differences in assemblage composition compared to the Norwegian Sea suggest the prevalence of cooler waters and the establishment of a temperature gradient between both regions across the MMCT. Palynological and geochemical methods both reveal a gradual cooling trend that initiated after the MCO, and using the $U^{K^{\prime}}{ }_{37}$ index, the maximum cooling of surface waters during this period is estimated to be $\sim 12{ }^{\circ} \mathrm{C}$. Superimposed, our palynomorph record depicts Miocene climate variability and transient alterations in the assemblages coincide with the MMCT (Mi-3a and Mi-3b) and the Mi-4 event, both presumably reflecting short-lived cooling periods in the Iceland Sea. Changes in dinocyst diversity and assemblage composition, however, slightly precede the Mi-5 event. Substantial changes in the surface water characteristics and the onset of progressive Late Miocene cooling is indicated between 10.6 and $10.2 \mathrm{Ma}$ (equivalent to Mi-6) by a pronounced cluster of species last occurrences and the first occurrence of the endemic cold-water acritarch $D$. martinheadii. In concert with a second major cluster of last occurrences between 9 and 8.4 Ma, which may coincide with Mi-7, this reflects the progressively strengthened influence of a proto-East Greenland Current in the Iceland Sea. The subsequent supraregional "Decahedrella event", and a contemporaneous SST decrease mark a general Late Miocene climate deterioration in the high northern latitudes at $~ 6.5 \mathrm{Ma}$. Indeed, most Neogene cooling occurred prior to $5.5 \mathrm{Ma}$, well before the initiation of large-scale Northern Hemisphere glaciations.

The earliest Pliocene is characterized by a transient warming, and enhanced productivity is likely related to surface stratification caused by freshwater discharge of melting icebergs/sea ice. However, the most distinctive feature of the Pliocene palynomorph record is a pronounced cluster of species disappearance between 4.5 and $4.3 \mathrm{Ma}$, probably related to the establishment of the modern East Greenland Current, and a subsequent crash of palynomorph accumulation that results in a conspicuous barren interval. Possible explanations for this interval invoke not only decreasing palynomorph productivity, enhanced bottom-water oxygenation due to increased Mid-Pliocene overturning circulation, and sea ice cover but probably also a bias introduced by sample resolution. However, the timing of these events significantly precedes the marked expansion of the Greenland Ice Sheet and suggests a sensible adaptation of the palynomorph assemblage to climate deterioration of a magnitude that does not led to traceable records in deep-sea sediments.

Supplementary data to this article can be found online at http:// dx.doi.org/10.1016/j.marmicro.2013.03.003.

\section{Acknowledgments}

This research uses samples and data provided by the Ocean Drilling Program (ODP), and Walter Hale and Alex Wülbers are thanked for technical support while sampling at the IODP Core Repository Bremen. J.M. and M.S. acknowledge support by the German Research Foundation (DFG MA 3913/2). We are very grateful to the Editor-in-Chief and two anonymous reviewers for constructive comments. Data supplement is available online at http://doi.pangaea.de/10.1594/PANGAEA. 807163.

\section{References}

Abels, H.A., Hilgen, F.J., Krijgsman, W., Kruk, R.W., Raffi, I., Turco, E., Zachariasse, W.J., 2005. Long-period orbital control on middle Miocene global cooling: integrated stratigraphy and astronomical tuning of the Blue Clay Formation on Malta. Paleoceanography 20, PA4012.
Abelson, M., Agnon, A., Almogi-Labin, A., 2008. Indications for control of the Iceland plume on the Eocene-Oligocene "greenhouse-icehouse" climate transition. Earth and Planetary Science Letters 265, 33-48.

Aksu, A.E., Hillaire-Marcel, C., 1989. Upper Miocene to Holocene oxygen and carbon isotopic stratigraphy of Sites 646 and 647, Labrador Sea. In: Srivastava, S.P., Arthur, M., Clement, B. (Eds.), Proceedings of the Ocean Drilling Program, Scientific Results, 105. Ocean Drilling Program, Texas A \& M University, College Station, Texas, pp. 689-704.

Aksu, A.E., Kaminski, M.A., 1989. Neogene and Quaternary planktonic foraminifera biostratigraphy and biochronology in Baffin Bay and Labrador Sea. In: Srivastava S.P., Arthur, M., Clement, B., et al. (Eds.), Proceedings of the Ocean Drilling Program, Scientific Results, 105. Ocean Drilling Program, Texas A \& M University, College Station, Texas, pp. 287-304.

Andersson, C., Jansen, E., 2003. A Miocene (8-12 Ma) intermediate water benthic stable isotope record from the northeastern Atlantic, ODP Site 982. Paleoceanography $18,1013$.

Andruleit, H., 1997. Coccolithophore fluxes in the Norwegian-Greenland Sea: seasonality and assemblage alterations. Marine Micropaleontology 31, 45-64.

Barton, A.D., Dutkiewicz, S., Flierl, G., Bragg, J., Follows, M.J., 2010. Patterns of diversity in marine phytoplankton. Science 327, 1509-1511.

Batten, D.J., 1996. Colonial Chlorococcales. In: Jansonius, J., McGregor, D.C. (Eds.), Palynology: Principles and Application, Volume 1 Principles. American Association of Stratigraphic Palynologists Foundation, Dallas, pp. 191-204.

Bendle, J., Rosell-Melé, A., 2004. Distributions of UK37 and UK'37 in the surface waters and sediments of the Nordic Seas: implications for paleoceanography. Geochemistry, Geophysics, Geosystems 5, Q11013.

Bendle, J., Rosell-Melé, A., Ziveri, P., 2005. Variability of unusual distributions of alkenones in the surface waters of the Nordic seas. Paleoceanography 20 PA2001.

Billups, K., Schrag, D.P., 2002. Paleotemperatures and ice volume of the past $27 \mathrm{Myr}$ revisited with paired $\mathrm{Mg} / \mathrm{Ca}$ and ${ }^{18} \mathrm{O} /{ }^{16} \mathrm{O}$ measurements on benthic foraminifera. Paleoceanography 17, 1003.

Blindheim, J., Østerhus, S., 2005. The Nordic Seas, main oceanographic features. In: Drange, H., Dokken, T., Furevik, T., Gerdes, R., Berger, W. (Eds.), The Nordic Seas An Integrated Perspective. American Geophysical Union, Washington, D.C., pp. 11-38

Bohrmann, G., Henrich, R. Thiede, J. 1990. Miocene to Quaternary paleoceanography in the northern North Atlantic: variability in carbonate and biogenic opal accumulation. In: Bleil, U., Thiede, J. (Eds.), Geological History of Polar Oceans: Arctic versus Antarctic. Kluwer Academic Publisher, Dordrecht, pp. 647-675.

Bonnet, S., de Vernal, A., Gersonde, R., Lembke-Jene, L., 2012. Modern distribution of dinocysts from the North Pacific Ocean (37-64 N, 144E-148 W) in relation to hydrographic conditions, sea ice and productivity. Marine Micropaleontology 84 87-113.

Bordovskiy, O.K., 1965. Sources of organic matter in marine basins. Marine Geology 3, 5-31.

Bremer, G.M.A., Smelror, M., Nagy, J., Vigram, J.O., 2004. Biotic responses to the Mjølnir meteorite impact, Barents Sea: evidence from a core drilled within the crater. In: Dypvik, H., Claeys, P., Burchell, M. (Eds.), Cratering in Marine Environments and on ice. Springer, Berlin, pp. 21-38.

Brenner, W., Biebow, N., 2001. Missing autofluorescence of recent and fossil dinoflagellate cysts - an indicator of heterotrophy? Neues Jahrbuch für Geologie und Paläntologie (Abhandlungen) 219, 229-240.

Butzin, M., Lohmann, G., Bickert, T., 2011. Miocene ocean circulation inferred from marine carbon cycle modeling combined with benthic isotope records. Paleoceanography 26 PA1203.

Channell, J.E.T., Amigo, A.E., Fronval, T., Rack, F., Lehman, B., 1999. Magnetic stratigraphy at Sites 907 and 985 in the Norwegian-Greenland Sea and a revision of the Site 907 composite section. In: Raymo, M.E., Jansen, E., Blum, P., Herbert, T.D. (Eds.), Proceedings of the Ocean Drilling Program, Scientific Results, 162. Ocean Drilling Program, Texas A \& M University, College Station, Texas, pp. 131-148.

Chen, B., Irwin, A.J., Finkel, Z.V., 2011. Biogeographic distribution of diversity and sizestructure of organic-walled dinoflagellate cysts. Marine Ecology Progress Series 425, 35-45.

Ciesielski, P.F., Case, M.S., 1989. Neogene paleoceanography of the Norwegian Sea based upon silicoflagellate assemblage changes in ODP Leg 104 sedimentary sequences. In: Eldholm, O., Thiede, J., Taylor, E., et al. (Eds.), Proceedings of the Ocean Drilling Program, Scientific Results, 104. Ocean Drilling Program, Texas A \& M University, College Station, Texas, pp. 527-542.

Conte, M.H., Sicre, M.-A., Rühlemann, C., Weber, J.C., Schulte, S., Schulz-Bull, D., Blanz, T., 2006. Global temperature calibration of the alkenone unsaturation index (UK' 37 ) in surface waters and comparison with surface sediments. Geochemistry, Geophysics, Geosystems 7, Q02005.

Cortese, G., Gersonde, R., Hillenbrand, C.-D., Kuhn, G., 2004. Opal sedimentation shifts in the World Ocean over the last 15 Myr. Earth and Planetary Science Letters 224, 509-527.

Costa, L.I., Downie, C., 1979. Cenozoic dinocyst stratigraphy of Sites 403 to 406 (Rockall Plateau) IPOD, Leg 48. In: Montadert, L., Roberts, D.G., et al. (Eds.), Initial Reports DSDP, 48. U.S. Government Printing Office, Washington, D.C., pp. 513-529.

De Schepper, S., Head, M.J., 2008. Age calibration of dinoflagellate cyst and acritarch events in the Pliocene-Pleistocene of the eastern North Atlantic (DSDP Hole 610A). Stratigraphy 5, 137-161.

De Schepper, S., Head, M.J., in press. New acritarchs from the Pliocene and earliest Pleistocene of the eastern North Atlantic. Journal of Systematic Paleontology.

De Schepper, S., Fischer, E., Groeneveld, J., Head, M.J., Matthiessen, J., 2011. Deciphering the palaeoecology of Late Pliocene and Early Pleistocene dinoflagellate cysts. Palaeogeography, Palaeoclimatology, Palaeoecology 309, 17-32. 
de Vernal, A., Mudie, P., 1989a. Late Pliocene to Holocene palynostratigraphy at ODP Site 645, Baffin Bay. In: Srivastava, S.P., Arthur, M., Clement, B., et al. (Eds.), Proceedings of the Ocean Drilling Program, Scientific Results, 105. Ocean Drilling Program, Texas A \& M University, College Station, Texas, pp. 387-399.

de Vernal, A., Mudie, P., 1989b. Pliocene and Pleistocene palynostratigraphy at ODP Sites 646 and 647, eastern and southern Labrador Sea. In: Srivastava, S.P., Arthur, M., Clement, B., et al. (Eds.), Proceedings of the Ocean Drilling Program, Scientific Results, 105. Ocean Drilling Program, Texas A \& M University, College Station, Texas, pp. 401-422.

de Vernal, A., Mudie, P., 1992. Pliocene and Quaternary dinoflagellate cyst stratigraphy in the Labrador Sea: paleoenvironmental implications. In: Head, M.J., Wrenn, J.H. (Eds.), Neogene and Quaternary Dinoflagellate Cysts and Acritarchs. American Association of Stratigraphic Palynologists Foundation, Dallas, Texas, pp. 329-346.

de Vernal, A., Henry, J., Matthiessen, J., Mudie, P., Rochon, A., Boessenkool, K.P., Eynaud, F., Grosfjeld, K., Guiot, J., Hamel, D., Harland, R., Head, M.J., Kunz-Pirrung, M., Levac, E., Loucheur, V., Peyron, O., Pospelova, V., Radi, T., Turon, J.L., Voronina, E., 2001. Dinflagellate cyst assemblages as tracers of sea-surface conditions in the northern North Atlantic, Arctic, and sub-Arctic seas: the new "n = 677" data base and its application for quantitative paleoceanographic reconstruction. Journal of Quaternary Science 16, 681-698.

Dekens, P.S., Ravelo, A.C., McCarthy, M.D., 2007. Warm upwelling regions in the Pliocene warm period. Paleoceanography 22, PA3211.

Denk, T., Grímsson, F., Kvaček, Z., 2005. The Miocene floras of Iceland and their significance for late Cainozoic North Atlantic biogeography. Botanical Journal of the Linnean Society 149, 369-417.

Denk, T., Grímsson, F., Zetter, R., Símonarson, L.A., 2011. Late Cenozoic Floras of Iceland 15 Million Years of Vegetation and Climate History in the Northern North Atlantic. Springer, Heidelberg (854 pp.).

Devillers, R., de Vernal, A., 2000. Distribution of dinoflagellate cysts in surface sediments of the northern North Atlantic in relation to nutrient content and productivity in surface waters. Marine Geology 166, 103-124.

Donders, T.H., Weijers, J.W.H., Munsterman, D.K., Kloosterboer-van Hoeve, M.L. Buckles, L.K., Pancost, R.D., Schouten, S., Sinninghe Damsté, J.S., Brinkhuis, H. 2009. Strong climate coupling of terrestrial and marine environments in the Miocene of northwest Europe. Earth and Planetary Science Letters 281, 215-225.

Edwards, L.E., Anderle, V.A.S., 1992. Distribution of selected dinoflagellate cysts in modern marine sediments. In: Head, M.J., Wrenn, J.H. (Eds.), Neogene and Quaternary Dinoflagellate Cysts and Acritarchs. American Association of Stratigraphic Palynologists Foundation, Dallas, Texas, pp. 259-288.

Eldrett, J.S., Harding, I.C., Wilson, P.A., Butler, E., Roberts, A.P., 2007. Continental ice in Greenland during the Eocene and Oligocene. Nature 446, 176-179.

Engel, E.R., 1992. Palynologische Evidenz klimarelevanter Ereignisse in miozänen Sedimenten des Nordatlantiks. Geologisches Jahrbuch A 125, 3-39.

Fensome, R.A., Williams, G.L., 2004. The Lentin and Williams Index of Fossil Dinoflagellates 2004 Edition. AASP Contributions Series, 42. American Association of Stratigraphic Palynologists Foundation, Dallas, Texas (909 pp.)

Fensome, R.A., Williams, G.L., Barss, M.S., Freeman, J.M., Hill, J.M., 1990. Acritarchs and fossil prasinophytes: an index to genera, species and infraspecific taxa. American Association of Stratigraphic Palynologists, Contributions Series, 25 1-771.

Firth, J.V., Clark, L.U., 1998. An early Maastrichtian organic-walled phytoplankton cyst assemblage from an organic-rich black mud in Core Fl-533, Alpha Ridge: evidence for upwelling conditions in the Cretaceous Arctic Ocean. Marine Micropaleontology $34,1-27$.

Flower, B.P., Kennett, J.P., 1994. The middle Miocene climatic transition: East Antarctic Ice Sheet development, deep ocean circulation and global carbon cycling. Palaeogeography, Palaeoclimatology, Palaeoecology 108, 537-555.

Fronval, T., Jansen, E., 1996. Late Neogene paleoclimates and paleoceanography in the Iceland-Norwegian Sea: evidence from the Iceland and Vøring Plateaus. In: Thiede, J., Myhre, A.M., Firth, J.V., Johnson, G.L. (Eds.), Proceedings of the Ocean Drilling Program, Scientific Results, 151. Ocean Drilling Program, Texas A \& M University, College Station, Texas, pp. 455-468.

Guy-Ohlson, 1996. Prasinophycean algae. In: Jansonius, J., McGregor, D.C. (Eds.) Palynology: Principles and Application, Volume 1 Principles. American Association of Stratigraphic Palynologists Foundation, Dallas, pp. 181-190.

Haley, B.A., Frank, M., Spielhagen, R., Fietzke, J., 2008. Radiogenic isotope record of Arctic Ocean circulation and weathering inputs of the past 15 million years Paleoceanography 23, PA1S13.

Hannah, M.J., Wrenn, J.H., Wilson, G.J., 1998. Early Miocene and Quaternary marine palynomorphs from Cape Roberts Project CRP-1, McMurdo Sound, Antarctica. Terra Antarctica 5, 527-538.

Hannah, M.J., Wilson, G.J., Wrenn, J.H., 2000. Oligocene and Miocene marine palynomorphs from CRP-2/2A, Victoria Land Basin, Antarctica. Terra Antarctica 7 503-511.

Harland, R., 1979. Dinoflagellate biostratigraphy of Neogene and Quaternary sediments at Holes 400/400A in the Bay of Biscaya (Deep Sea Drilling Project Leg 48). In: Montadert, L., Roberts, D.G., et al. (Eds.), Initial Report DSDP 48. U.S. Government Printing Office, Washington, D.C. pp. 531-545.

Haug G.H. Tiedemann, R. 1998. Effect of the formation of the Isthmus of Panama on Atlantic Ocean thermohaline circulation. Nature 393, 673-676.

Head, M.J., 2003. Neogene occurrences of the marine acritarch genus Nannobarbophora Habib and Knapp, 1982 emend., and the new species N. gedlii. Journal of Paleontology 77, 382-385.

Head, M.J., Norris, G., Mudie, P., 1989a. New species of dinocysts and a new species of acritarch from the upper Miocene and lowermost Pliocene, ODP Leg 105, Site 646, Labrador Sea. In: Srivastava, S.P., Arthur, M., Clement, B., et al. (Eds.), Proceedings of the Ocean Drilling Program, Scientific Results, 105. Ocean Drilling Program, Texas A \& M University, College Station, Texas, pp. 453-466

Head, M.J., Norris, G., Mudie, P., 1989b. Palynology and dinocyst stratigraphy of the upper Miocene and lowermost Pliocene, ODP Leg 105, Site 646, Labrador Sea. In: Srivastava, S.P., Arthur, M. Clement, B. et al. (Eds.), Proceedings of the Ocean Drilling Program, Scientific Results, 105. Ocean Drilling Program, Texas A \& M University, College Station, Texas, pp. 423-451.

Head, M.J., Norris, G., Mudie, P., 1989c. Palynology and dinocyst stratigraphy of the Miocene in ODP Leg 105, Hole 645E, Baffin Bay. In: Srivastava, S.P., Arthur, M., Clement, B., et al. (Eds.), Proceedings of the Ocean Drilling Program, Scientific Results, 105. Ocean Drilling Program, Texas A \& M University, College Station, Texas, pp. 467-514.

Hegewald, A., Jokat, W., 2013. Relative sea level variations in the Chukchi region-Arctic Ocean - since the late Eocene. Geophysical Research Letters 40. http://dx.doi.org/ 10.1002/grl.50182 (GRL.50182).

Helland, P.E., Holmes, M.A., 1997. Surface textural analysis of quartz sand grains from ODP Site 918 off the southeast coast of Greenland suggests glaciation of southern Greenland at $11 \mathrm{Ma}$. Palaeogeography, Palaeoclimatology, Palaeoecology $135,109-121$.

Henrich, R., Wolf, T., Bohrmann, G., Thiede, J., 1989. Cenozoic paleoclimatic and paleoceanographic changes in the Northern Hemisphere revealed by variability of coarse-fraction composition in sediments from the Vøring Plateau - ODP Leg 104 drill sites. In: Eldholm, O., Thiede, J., Taylor, E., et al. (Eds.), Proceedings of the Ocean Drilling Program, Scientific Results, 104. Ocean Drilling Program, Texas A \& M University, College Station, Texas, pp. 75-188.

Herbert, T.D., Schuffert, J.D., 1998. Alkenone unsaturation estimates for Late Miocene through Late Pliocene sea-surface temperatures at Site 985. In: Firth, J.V. (Ed.), Proceedings of the Ocean Drilling Program, Scientific Results, 159T. Ocean Drilling Program, Texas A \& M University, College Station, Texas, pp. 17-21.

Hodell, D.A., Kennett, J.P., 1986. Late Miocene-Early Pliocene stratigraphy and paleoceanography of the South Atlantic and southwest Pacific oceans: a synthesis. Paleoceanography 1, 285-311.

Hodell, D.A., Curtis, J.H., Sierro, F.J., Raymo, M.E., 2001. Correlation of Late Miocene to Early Pliocene sequences between the Mediterranean and North Atlantic. Paleoceanography $16,164-178$

Holzwarth, U., Esper, O., Zonneveld, K.A.F., 2010. Organic-walled dinoflagellate cysts as indicators of oceanographic conditions and terrigenous input in the NW African upwelling region. Review of Palaeobotany and Palynology 159, 35-55.

Huang, Y., Clemens, S.C., Liu, W., Wang, Y., Prell, W.L., 2007. Large-scale hydrological change drove the late Miocene C4 plant expansion in the Himalayan foreland and Arabian Peninsula. Geology 35, 531-534

Jacobson, D.M., Anderson, D.M., 1986. Thecate heterotrophic dinoflagellates: feeding behaviour and mechanisms. Journal of Phycology 22, 249-258.

Jakobsson, M., Backman, J., Rudels, B., Nycander, J., Frank, M., Mayer, L., Jokat, W., Sangiorgi, F., O'Regan, M., Brinkhuis, H., King, J., Moran, K., 2007. The early Miocene onset of a ventilated circulation regime in the Arctic Ocean. Nature 447, 986-990.

Jansen, E., Sjøholm, J., 1991. Reconstruction of glaciation over the past 6 Myr from ice-born deposits in the Norwegian Sea. Nature 349, 600-603.

Jansen, E., Raymo, M.E., Blum, P., 1996. Proceedings of the Ocean Drilling Program, Initial Reports, 162 (1182 pp.).

Jansen, E., Fronval, T., Rack, F., Channell, J.E.T., 2000. Pliocene-Pleistocene ice rafting history and cyclicity in the Nordic Seas during the last 3.5 Myr. Paleoceanography 15, 709-721.

Japsen, P., Bonow, J.M., Green, P.F., Chalmers, J.A., Lidmar-Bergström, K., 2006. Elevated, passive continental margins: long-term highs or Neogene uplifts? New evidence from West Greenland. Earth and Planetary Science Letters 248, 330-339.

Jiménez-Moreno, G., Head, M.J., Harzhauser, M., 2006. Early and Middle Miocene dinoflagellate cyst stratigraphy of the Central Paratethys, Central Europe. Journal of Micropalaeontology 25, 113-119.

John, C.M., Karner, G.D., Browning, E., Leckie, R.M., Mateo, Z., Carson, B., Lowery, C., 2011. Timing and magnitude of Miocene eustasy derived from the mixed siliciclastic-carbonate stratigraphic record of the northeastern Australian margin. Earth and Planetary Science Letters 304, 455-467.

Kaminski, M.A., 2007. Fauna constraints for the timing of the Fram Strait opening: the record of Miocene deep-water agglutinated foraminifera from IODP Hole M0002A, Lomonosov Ridge. IODP Newsletter UK 32, 18-20.

Kaminski, M.A., Silye, L., Kender, S., 2006. Miocene deep-water agglutinated foraminifera from ODP Hole 909C: implications for the paleoceanography of the Fram Strait Area, Greenland Sea. Micropaleontology 51, 373-403.

Kleiven, H.F., Jansen, E., Fronval, T., Smith, T.M., 2002. Intensification of Northern Hemisphere glaciations in the circum Atlantic region (3.5-2.4 Ma) - ice-rafted detritus evidence. Palaeogeography, Palaeoclimatology, Palaeoecology 184, 213-223.

Knies, J., Gaina, C., 2008. Middle Miocene ice sheet expansion in the Arctic: views from the Barents Sea. Geochemistry, Geophysics, Geosystems 9, Q02015.

Koc, N., Scherer, R.P., 1996. Neogene diatom biostratigraphy of the Iceland Sea Site 907. In: Thiede, J., Myhre, A.M., Firth, J.V., Johnson, G.L., Ruddiman, W.F. (Eds.), Proceedings of the Ocean Drilling Program, Scientific Results, 151. Ocean Drilling Program, Texas A \& M University, College Station, Texas, pp. 61-74.

Krebs, C.J., 1998. Ecological Methodology. Addison-Wesley Educational Publishers, Menlo Park (620 pp.)

Kuhnert, H., Bickert, T., Paulsen, H., 2009. Southern Ocean frontal system changes precede Antarctic Ice Sheet growth during the middle Miocene. Earth and Planetary Science Letters 284, 630-638.

LaRiviere, J.P., Ravelo, A.C., Grimmins, A., Dekens, P., Ford, H.L., Lyle, M., Wara, M.W., 2012. Late Miocene decoupling of oceanic warmth and atmospheric carbon dioxide. Nature 486, 97-100. 
Lawrence, K.T., Herbert, T.D., Brown, C.M., Raymo, M.E., Haywood, A.M., 2009. Highamplitude variations in North Atlantic sea surface temperature during the early Pliocene warm period. Paleoceanography 24, PA2218.

Lawrence, K.T., Sosdian, S., White, H.E., Rosenthal, Y., 2010. North Atlantic climate evolution through the Plio-Pleistocene climate transitions. Earth and Planetary Science Letters 300, 329-342.

Locker, S., Martini, E., 1989. Cenozoic silicoflagellates, ebridians, and actiniscidians from the Vøring Plateau (ODP Leg 104). In: Eldholm, O., Thiede, J., Taylor, E., et al. (Eds.), Proceedings of the Ocean Drilling Program, Scientific Results, 104. Ocean Drilling Program, Texas A \& M University, College Station, Texas, pp. 543-586.

Lourens, L., Hilgen, F., Shackleton, N.J., Laskar, J., Wilson, J., 2005. The Neogene. In: Gradstein, F.M., Ogg, J.G., Smith, A.G. (Eds.), A Geological Timescale 2004. Cambridge University Press, Cambridge, U.K., pp. 409-430 (Imprinted 2004).

Ma, W., Tian, J., Li, Q., Wang, P., 2011. Simulation of long eccentricity (400-kyr) cycle in ocean carbon reservoir during Miocene Climate Optimum: weathering and nutrient response to orbital change. Geophysical Research Letters 38, L10701.

Manum, S.B., 1997. Decahedrella martinheadii gen. et sp. nov. - a problematic palynomorph from the Northern Atlantic Miocene. Palynology 21, 67-77.

Manum, S.B., Boulter, M.C., Gunnarsdottir, H., Rangnes, K., Scholze, A., 1989. Eocene to Miocene Palynology of the Norwegian Sea (ODP Leg 104). In: Eldholm, O., Thiede, J., Taylor, E., et al. (Eds.), Proceedings of the Ocean Drilling Program, Scientific Results, 104. Ocean Drilling Program, Texas A \& M University, College Station, Texas, pp. 611-662.

Marlowe, I.T., Brassell, S.C., Eglinton, G., Green, J.C., 1990. Long-chain alkenones and alkyl alkenoates and the fossil coccolith record of marine sediments. Chemical Geology 88, 349-375.

Marret, F., Zonneveld, K.A.F., 2003. Atlas of modern organic-walled dinoflagellate cyst distribution. Review of Palaeobotany and Palynology 125, 1-200.

Marret, F., Eiríksson, J., Knudsen, K.L., Turon, J.-L., Scourse, J.D., 2004. Distribution of dinoflagellate cyst assemblages in surface sediments from the northern and western shelf of Iceland. Review of Palaeobotany and Palynology 128, 35-53.

Matthiessen, J., 1995. Distribution patterns of dinoflagellate cysts and other organicwalled microfossils in recent Norwegian-Greenland Sea sediments. Marine Micropaleontology 24, 307-334.

Matthiessen, J., Knies, J., Nowaczyk, N.R., Stein, R., 2001. Late Quaternary dinoflagellate cyst stratigraphy at the Eurasian continental margin, Arctic Ocean: indications for Atlantic water inflow in the past 150,000 years. Global and Planetary Change 31, 65-86.

Matthiessen, J., Brinkhuis, H., Poulsen, N.E., Smelror, M., 2009. Decahedrella martinheadii Manum, 1997 - a stratigraphically and paleoenvironmentally useful Miocene acritarch of the northern high latitudes. Micropaleontology 55, 171-186.

McClymont, E.L., Rosell-Melé, A., Giraudeau, J., Pierre, C., Lloyd, J.M., 2005. Alkenone and coccolith records of the mid-Pleistocene in the south-east Atlantic: implications for the index and South African climate. Quaternary Science Reviews 24, 1559-1572.

Mercer, J.L., Zhao, M., 2004. Alkenone stratigraphy of the northern South China Sea for the past 35 m.y., Sites 1147 and 1148, ODP Leg 184. In: Prell, W.L., Wang, P., Blum, P., Rea, D.K. (Eds.), Proceedings of the Ocean Drilling Program, Scientific Results, 184. Ocean Drilling Program, Texas A \& M University, College Station, Texas, pp. 1-17.

Miller, K.G., Mountain, G.S., 1996. Drilling and dating New Jersey Oligocene-Miocene sequences: ice volume, global sea level, and Exxon records. Science 271, 1092-1095.

Miller, K.G., Wright, J.D., Fairbanks, R.G., 1991. Unlocking the Ice House: OligoceneMiocene oxygen isotopes, eustasy, and margin erosion. Journal of Geophysical Research 96, 6829-6848.

Miller, K.G., Mountain, G.S., Browning, J.V., Kominz, M., Sugarman, P.J., Christie-Blick, N., Katz, M.E., Wright, J.D., 1998. Cenozoic global sea level, sequences, and the New Jersey Transect: results from coastal plain and continental slope drilling. Reviews of Geophysics 36, 569-601.

Miller, G.H., Alley, R.B., Brigham-Grette, J., Fitzpatrick, J.J., Polyak, L., Serreze, M.C., White, J.W.C., 2010. Arctic amplification: can the past constrain the future? Quaternary Science Reviews 29, 1779-1790.

Mosbrugger, V., Utescher, T., Dilcher, D., 2005. Cenozoic continental climatic evolution of Central Europe. Proceedings of the National Academy of Sciences 102, 14964-14969.

Mourik, A.A., Abels, H.A., Hilgen, F.J., Di Stefano, A., Zachariasse, W.J., 2011. Improved astronomical age constraints for the middle Miocene climate transition based on high-resolution stable isotope records from the central Mediterranean Maltese Islands. Paleoceanography 26, PA1210.

Mudie, P., 1987. Palynology and dinoflagellate biostratigraphy of Deep Sea Drilling Project Leg 94, Sites 607 and 611, North Atlantic Ocean. In: Ruddiman, W.F., Kidd, R.B., Thomas, E., et al. (Eds.), Initial Reports DSDP, 94. U.S. Government Printing Office, Washington, D.C., pp. 785-812.

Mudie, P., 1989. Palynology and Dinocyst Biostratigraphy of the Late Miocene to Pleistocene, Norwegian Sea: ODP Leg 104, Sites 642 to 644. In: Eldholm, O., Thiede, J., Taylor, E., et al. (Eds.), Proceedings of the Ocean Drilling Program, Scientific Results, 104. Ocean Drilling Program, Texas A \& M University, College Station, Texas, pp. 587-610.

Mudie, P., 1992. Circum-Arctic Quaternary and Neogene marine palynofloras: paleoecology and statistical analysis. In: Head, M.J., Wrenn, J.H. (Eds.), Neogene and Quaternary Dinoflagellate Cysts and Acritarchs. American Association of Stratigraphic Palynologists Publications, Dallas, pp. 347-390.

Mudie, P., Helgason, J., 1983. Palynological evidence for Miocene climatic cooling in eastern Iceland about 9.8 Ma. Nature 303, 689-692.

Mudie, P., de Vernal, A., Head, M.J., 1990. Neogene to recent palynostratigraphy of circum-Arctic basins: results of ODP Leg 104, Norwegian Sea, Leg 105, Baffin Bay, and DSDP Site 611, Irminger Sea. In: Bleil, U., Thiede, J. (Eds.), Geological History of Polar Oceans: Arctic versus Antarctic. Kluwer Academic Publisher, Dordrecht, pp. 609-646.

Müller, P.J., Kirst, G., Ruhland, G., von Storch, I., Rosell-Melé, A., 1998. Calibration of the alkenone paleotemperature index $\mathrm{UK}^{\prime} 37$ based on core-tops from the eastern South Atlantic and the global ocean $\left(60^{\circ} \mathrm{N}-60^{\circ} \mathrm{S}\right)$. Geochimica et Cosmochimica Acta $62,1757-1772$

Naafs, B.D.A., Stein, R., Hefter, J., Khèlifi, N., De Schepper, S., Haug, G.H., 2010. Late Pliocene changes in the North Atlantic Current. Earth and Planetary Science Letters $298,434-442$.

Pagani, M., Freeman, K.H., Arthur, M.A., 1999. Late Miocene atmospheric $\mathrm{CO}_{2}$ concentrations and the expansion of C4 grasses. Science 285, 876-879.

Paschier, S., Browne, G., Field, B., Fielding, C.R., Krissek, L.A., Panter, K., Pekar, S.F., the Andrill Scientific Team, 2011. Early and middle Miocene Antarctic glacial history from the sedimentary facies distribution in the AND-2A drill hole, Ross Sea, Antarctica. Geological Society of America Bulletin 123, 2352-2365.

Piasecki, S., 2003. Neogene dinoflagellate cysts from Davis Strait, offshore West Greenland. Marine and Petroleum Geology 20, 1075-1088.

Poore, H.R., Samworth, R., White, N.J., Jones, S.M., McCave, I.N., 2006. Neogene overflow of Northern Component Water at the Greenland-Scotland Ridge. Geochemistry, Geophysics, Geosystems 7, Q06010.

Pound, M.J., Haywood, A.M., Salzmann, U., Riding, J.B., 2012. Global vegetation dynamics and latitudinal temperature gradients during the Mid to Late Miocene (15.97-5.33 Ma). Earth-Science Reviews 112, 1-22.

Prauss, M., Riegel, W., 1989. Evidence from phytoplankton associations for causes of black shale formation in epicontinental seas. Neues Jahrbuch für Geologie und Paläontologie 11, 671-682.

Radi, T., de Vernal, A., 2008. Dinocysts as proxy of primary productivity in mid-high latitudes of the Northern Hemisphere. Marine Micropaleontology 68, 84-114.

Rahmstorf, S., 2006. Thermohaline ocean circulation. In: Elias, A. (Ed.), Encyclopedia Quaternary Sciences. Elsevier, Amsterdam, pp. 1-10.

Reichart, G.-J., Brinkhuis, H., 2003. Late Quaternary protoperidinium cysts as indicators of paleoproductivity in the northern Arabian Sea. Marine Micropaleontology 49, 303-315

Robinson, M.M., 2009. New quantitative evidence of extreme warmth in the Pliocene Arctic. Stratigraphy 6, 265-275.

Robinson, M.M., Valdes, P.J., Haywood, A.M., Dowsett, H.J., Hill, D.J., Jones, S.M., 2011 Bathymetric controls on Pliocene North Atlantic and Arctic Sea surface temperature and deepwater production. Palaeogeography, Palaeoclimatology, Palaeoecology 309, 92-97.

Rochon, A., De Vernal, A., Turon, J.L., Matthiessen, J., Head, M.J., 1999. Distribution of recent dinoflagellate cysts in surface sediments from the North Atlantic Ocean and adjacent seas in relation to sea-surface parameters. AASP Contribution Series, No. 35. American Association of Stratigraphic Palynologists Foundation, Dallas (1-152 pp.).

Rommerskirchen, F., Condon, T., Mollenhauer, G., Dupont, L., Schefuss, E., 2011. Miocene to Pliocene development of surface and subsurface temperatures in the Benguela Current system. Paleoceanography 26, PA3216.

Rousselle, G., Beltran, C., Sicre, M.-A., Raffi, I., De Rafélis, M., 2013. Changes in seasurface conditions in the Equatorial Pacific during the middle Miocene-Pliocene as inferred from coccolith geochemistry. Earth and Planetary Science Letters 361 $412-421$.

Salzmann, U., Williams, M., Haywood, A.M., Johnson, A.L.A., Kender, S., Zalasiewicz, J., 2011. Climate and environment of a Pliocene warm world. Palaeogeography Palaeoclimatology, Palaeoecology 309, 1-8.

Sarnthein, M., Bartoli, G., Prange, M., Schmittner, A., Schneider, B., Weinelt, M., Andersen, N., Garbe-Schönberg, D., 2009. Mid-Pliocene shifts in ocean overturning circulation and the onset of Quaternary-style climates. Climate of the Past 5 269-283.

Schaeffer, R., Spiegler, D., 1986. Neogene Kälteeinbrüche und Vereisungsphasen im Nordatlantik. Zeitschrift der Deutschen Geologischen Gesellschaft 137 537-552.

Schreck, M., Matthiessen, J., in press. Batiacasphaera micropapillata - palaeobiogeographic distribution and palaeoecological implications of a critical Neogene species complex, in: Lewis, J.M., Marret, F., Bradley, L. (Eds.), Biological and geological perspectives of dinoflagellates. The Micropaleontological Society, Special Publications. The Geological Society, London.

Schreck, M., Matthiessen, J., Head, M.J., 2012. A magnetostratigraphic calibration of Middle Miocene through Pliocene dinoflagellate cyst and acritarch events in the Iceland Sea (Ocean Drilling Program Hole 907A). Review of Palaeobotany and Palynology 187, 66-94.

Schröder-Ritzrau, A., Andruleit, H., Jensen, S., Samtleben, C., Schäfer, P., Matthiessen, J. Hass, C., Kohly, A., Thiede, J., 2001. Distribution, export and alteration of fossilizable plankton in the Nordic Seas. In: Schäfer, P., Ritzrau, W., Schlüter, M., Thiede, J. (Eds.), The Northern North Atlantic - A Changing Environment. Springer, Berlin, pp. 81-104.

Seki, O., Schmidt, D.N., Schouten, S., Hopmans, E.C., Sinninghe Damsté, J.S., Pancost, R.D., 2012. Paleoceanographic changes in the Eastern Equatorial Pacific over the last 10 Myr. Paleoceanography 27, PA3224.

Serreze, M.C., Barry, R.G., 2011. Processes and impacts of Arctic amplification: a research synthesis. Global and Planetary Change 77, 85-96.

Shevenell, A.E., Kennett, J.P., Lea, D.W., 2004. Middle Miocene Southern Ocean cooling and Antarctic cryosphere expansion. Science 305, 1766-1770.

Shipboard Scientific Party, 1995. Site 907. In: Myhre, A.M., Thiede, J., Firth, J.V., et al. (Eds.), Proceedings of the Ocean Drilling Program, Initial Reports, 151. Ocean Drilling Program, Texas A \& M University, College Station, Texas, pp. 57-111.

Sorrel, P., Popescu, S.-M., Head, M.J., Suc, J.P., Klotz, S., Oberhänsli, H., 2006. Hydrographic development of the Aral Sea during the last 2000 years based on quantitative analysis 
of dinoflagellate cysts. Palaeogeography, Palaeoclimatology, Palaeoecology 234 , 304-327.

St. John, K., 2008. Cenozoic ice-rafting history of the central Arctic Ocean: terrigenous sands on the Lomonosov Ridge. Paleoceanography 23, PA1S05.

St. John, K., Krissek, L.A., 2002. The late Miocene to Pleistocene ice-rafting history of southeast Greenland. Boreas 31, 28-35.

Stabell, B., Koç, N., 1996. Recent to Middle Miocene diatom productivity at Site 907, Iceland Plateau. In: Thiede, J., Myhre, A.M., Firth, J.V., Johnson, G.L., Ruddiman, W.F. (Eds.), Proceedings of the Ocean Drilling Program, Scientific Results 151, 483-492.

Stein, R., 1991. Organic carbon accumulation in Baffin Bay and paleoenvironment in high northern latitudes during the past 20 My. Geology 19, 356-359.

Stein, R., 2008. Arctic Ocean Sediments - Processes, Proxies and Paleoenvironment. Elsevier, Amsterdam (592 pp.)

Stein, R., Macdonald, R.W., 2004. Geochemical proxies used for organic carbon source identification in Arctic Ocean sediments. In: Stein, R., Mcdonald, R.W. (Eds.), The Organic Carbon Cycle in the Arctic Ocean. Springer, Heidelberg, pp. 24-32.

Stickley, C.E., St John, K., Koç, N., Jordan, R.W., Passchier, S., Pearce, R.B., Kearns, L.E. 2009. Evidence for middle Eocene Arctic Sea ice from diatoms and ice-rafted debris. Nature 460, 376-379.

Stockmarr, J., 1977. Tablets with spores used in absolute pollen analysis. Pollen et Spores 13, 615-621.

Strother, P.K., 1996. Acritarchs. In: Jansonius, J., McGregor, D.C. (Eds.), Palynology: Principles and Application, Volume 1 Principles. American Association of Stratigraphic Palynologists Foundation, Dallas, pp. 81-106.

Tappan, H., 1980. The Paleobiology of Plant Protists. W.H. Freeman and Company, San Francisco (1028 pp.).

Thiébault, F., Cremer, M., Debrabant, P., Foulon, J., Nielsen, O.B., Zimmerman, H., 1989 Analysis of sedimentary facies, clay mineralogy, and geochemistry of the Neogene Quaternary sediments in ODP Site 645, Baffin Bay. In: Srivastava, S.P., Arthur, M. Clement, B., et al. (Eds.), Proceedings of the Ocean Drilling Program, Scientific Results, 105. Ocean Drilling Program, Texas A \& M University, College Station, Texas, pp. 83-100.

Thiede, J.R., Winkler, A., Wolf-Welling, T., Eldholm, O., Myhre, A.M., Baumann, K.-H Henrich, R., Stein, R., 1998. Late Cenozoic history of the polar North Atlantic: results from Ocean Drilling. Quaternary Science Reviews 17, 185-208.

Thiede, J. Jessen, C. Knutz, P. Kuijpers, A, Mikkelsen, N. Nørgaard-Pedersen, $N$ Spielhagen, R., 2011. Millions of years of Greenland Ice Sheet history recorded in ocean sediments. Polarforschung 80, 141-159.

Thierstein, H.R., Geitzenauer, K.R., Molfino, B., Shackleton, N.J., 1977. Global synchroneity of late Quaternary coccolith datum levels: validation by oxygen isotopes. Geology 5 , 400-404.

Thomson, K., Green, P.F., Whitham, A.G., Price, S.P., Underhill, J.R., 1999. New constraints on the thermal history of North-East Greenland from apatite fissontrack analysis. Geological Society of America Bulletin 111, 1054-1068.

Tripati, A.K., Eagle, R.A., Morton, A., Dowdeswell, J.A., Atkinson, K.L., Bahé, Y., Dawber C.F., Khadun, E., Shaw, R.M.H., Shorttle, O., Thanabalasundaram, L., 2008. Evidence for glaciation in the Northern Hemisphere back to $44 \mathrm{Ma}$ from ice-rafted debris in the Greenland Sea. Earth and Planetary Science Letters 265, 112-122.

Turco, E., Hilgen, F.J., Lourens, L.J., Shackleton, N.J., Zachariasse, W.J., 2001. Punctuated evolution of global climate cooling during the late Middle to early Late Miocene: high-resolution planktonic foraminiferal and oxygen isotope records from the Mediterranean. Paleoceanography 16, 405-423.

Tyson, R.V., 1995. Sedimentary Organic Matter - Organic Facies and Palynofacies. Chapman \& Hall, London (615 pp.).

Van Nieuwenhove, N., Bauch, H.A., Matthiessen, J., 2007. Last interglacial surface water conditions in the eastern Nordic Seas inferred from dinocyst and foraminiferal assemblages. Marine Micropaleontology 66, 247-263.

Verhoeven, K., Louwye, S., Eirìksson, J., De Schepper, S., 2011. A new age model for the Pliocene-Pleistocene Tjörnes section on Iceland: its implication for the timing of North Atlantic-Pacific palaeoceanographic pathways. Palaeogeography, Palaeoclimatology, Palaeoecology 309, 33-52.

Versteegh, G.J.M., Zonneveld, K.A.F., de Lange, G.J., 2010. Selective aerobic and anaerobic degradation of lipids and palynomorphs in the Eastern Mediterranean since the onset of sapropel S1 deposition. Marine Geology 278, 177-192.

Villanueva, J., Flores, J.A., Grimalt, J.O., 2002. A detailed comparison of the UK'37 and coccolith records over the past $290 \mathrm{ky}$ : implications to the alkenone paleotemperature method. Organic Geochemistry 33, 897-905.

Volkman, J.K., Barrerr, S.M., Blackburn, S.I., Sikes, E.L., 1995. Alkenones in Gephyrocapsa oceanica: implications for studies of paleoclimate. Geochimica et Cosmochimica Acta 59, 513-520.
Wall, D., Dale, B., 1974. Dinoflagellates in the Late Quaternary deep-water sediments of the Black Sea. In: Degens, E.T., Ross, D.A. (Eds.), The Black Sea - Geology, Chemistry and Biology. American Association of Petroleum Geologists, Tulsa, TX, pp. 364-380.

Wall, D., Dale, B., Harada, K., 1973. Descriptions of new fossil dinoflagellates from the Late Quaternary of the Black Sea. Micropaleontology 19, 18-31.

Wan, S., Kürschner, W.M., Clift, P.D., Li, A., Li, T., 2009. Extreme weathering/erosion during the Miocene Climatic Optimum: evidence from sediment record in the South China Sea. Geophysical Research Letters 36, L19706.

Wei, W., 1998. Calcareous nannofossils from the southeast Greenland margin: biostratigraphy and paleoceanography. In: Saunders, A.D., Larsen, H.C., Wise, S.W. (Eds.), Proceedings of the Ocean Drilling Program, Scientific Results, 152. Ocean Drilling Program, Texas A \& M University, College Station, Texas, pp. 147-160.

Weller, P., Stein, R., 2008. Paleogene biomarker records from the central Arctic Ocean (Integrated Ocean Drilling Program Expedition 302): organic carbon sources, anoxia, and sea surface temperature. Paleoceanography 23, PA1S17.

Westerhold, T., Bickert, T., Röhl, U., 2005. Middle to late Miocene oxygen isotope stratigraphy of ODP site 1085 (SE Atlantic): new constraints on Miocene climate variability and sea-level fluctuations. Palaeogeography, Palaeoclimatology, Palaeoecology 217, 205-222.

Winkler, A., Wolf-Welling, T.C.W., Stattegger, K., Thiede, J., 2002. Clay mineral sedimentation in high northern latitudes deep-sea basins since the Middle Miocene (ODP Leg 151, NAAG). International Journal of Earth Sciences 91, $133-148$.

Wold, C.N., 1994. Cenozoic sediment accumulation on drifts in the northern North Atlantic. Paleoceanography 9, 917-941.

Wolf, T.C.W., Thiede, J., 1991. History of terrigenous sedimentation during the past 10 m.y. in the North Atlantic (ODP Legs 104 and 105, and DSDP Leg 81). Marine Geology 101, 83-102.

Wolf-Welling, T.C.W., Cremer, M., O'Connell, S., Winkler, A., Thiede, J., 1996. Cenozoic Arctic gateway paleoclimate variability: indications from changes in coarsefraction composition. In: Thiede, J., Myhre, A.M., Firth, J.V., Johnson, G.L., Ruddiman, W. (Eds.) Proceedings of the Ocean Drilling Program, Scientific Results, 151. Ocean Drilling Program, Texas A \& M University, College Station, Texas, pp. 515-567.

Wood, G.D. Gabriel, A.M. Lawson, J.C. 1996. Palynological techniques - processing and microscopy. In: Jansonius, J., McGregor, D.C. (Eds.), Palynology: Principles and Applications, Volume 1 Principles. American Association of Stratigraphic Palynologists Foundation, Dallas, pp. 29-50.

Wright, J.D., Miller, K.G., 1992. Miocene stable isotope stratigraphy, Site 747, Kerguelen Plateau. In: Wise, S.W.J., Schlich, R., et al. (Eds.), Proceedings of the Ocean Drilling Program, Scientific Results, 120. Ocean Drilling Program, Texas A \& M University, College Station, Texas, pp. 855-866.

Wright, J.D., Miller, K.G., 1996. Control of North Atlantic deep water circulation by the Greenland-Scotland Ridge. Paleoceanography 11, 157-170.

Wright, J.D., Miller, K.G., Fairbanks, R.G., 1992. Early and Middle Miocene stable isotopes: implications for deepwater circulation and climate. Paleoceanography 7, 357-389.

Zachos, J., Pagani, M., Sloan, L., Thomas, E., Billups, K., 2001. Trends, rhythms, and aberrations in global climate $65 \mathrm{Ma}$ to present. Science 292, 686-693.

Zachos, J., Dicken, G.R., Zeebe, R.E., 2008. An early Cenozoic perspective on greenhouse warming and carbon-cycle dynamics. Nature 451, 279-283.

Zonneveld, K.A.F., Versteegh, G., Kodrans-Nsiah, M., 2008. Preservation and organic chemistry of Late Cenozoic organic-walled dinoflagellate cysts: a review. Marine Micropaleontology 68, 179-197.

Zonneveld, K.A.F., Versteegh, G.J.M., Kasten, S., Eglinton, T.I., Emeis, K.-C., Huguet, C., Koch, B.P., de Lange, G.J., de Leeuw, J.W., Middelburg, J.J., Mollenhauer, G., Prahl, F.G., Rethemeyer, J., Wakeham, S.G., 2010. Selective preservation of organic matter in marine environments; processes and impact on the sedimentary record. Biogeosciences 7, 483-511.

Zonneveld, K.A.F., Marret, F., Versteegh, G., Bogus, K., Bonnet, S., Bouimetarhan, I. Crouch, E., de Vernal, A., Elshanawany, R., Edwards, L., Esper, O., Forke, S., Grøsfjeld, K., Henry, M., Holzwarth, U., Kielt, J.F., Kim, S.Y., Ladouceur, S., Ledu, D., Liang, C., Limoges, A., Londeix, L., Lu, S.H., Mahmoud, M.S., Marino, G., Matsouka, K., Matthiessen, J., Mildenhal, D.C., Mudie, P., Neil, H.L., Pospelova, V., Qi, Y., Radi, T., Richerol, T., Rochon, A., Sangiorgi, F., Solignac, S., Turon, J.L., Verleye, T., Wang, T., Wang, Z., Young, M., 2012. Atlas of modern dinoflagellate cyst distribution based on 2405 datapoints. Review of Palaeobotany and Palynology in press. 